\title{
The distribution of trimoraic syllables in German and English as evidence for the phonological word
}

\author{
T. A. Hall \\ University of Leipzig
}

\section{Introduction}

The following English and German words contain what I refer to below as 'trimoraic syllables', i.e. the underlined portion consists of either (i) a long vowel + one consonant, (ii) a diphthong + a single consonant or (iii) a short vowel + two consonants. In approaches to phonology in which vowel and consonant length is expressed in terms of moras all of the underlined strings in (1) can thought of as consisting of three such units. In (1) and below all German examples are presented in the left hand column and the English ones in the right.

(1a) Trimoraic syllables in word-final position:

$$
\text { Werk 'work' } \underline{\text { arm }}
$$

(1b) Trimoraic syllables before a compound boundary:

$$
\text { Werk-statt 'workshop' } \underline{\text { arm-chair }}
$$

(1c) Trimoraic syllables before a consonant-initial suffix:

$$
\text { fünf-zig 'fifty' event-ful }
$$

Three contexts in which trimoraic syllables occur can be gleaned from (1), i.e. before a word boundary in (1a), before a compound boundary in (1b) and before a consonant-initial suffix in (1c), i.e. a suffix of the form $-\mathrm{CV}(\mathrm{C})$.

An important generalization governing trimoraic syllables in German and English is that they are, in general, restricted to surfacing in the three environments in (1). By contrast, underlined sequences like the ones in (1) are typically non-occurring morpheme-internally; thus, the moraic portion in the vast majority of morpheme-internal syllables is bipositional, e.g. German Garten, English garden. An important point made below is that under certain completely predictable conditions, trimoraic syllables in both languages can indeed surface within a morpheme, e.g. German Mond-e 'moons', English chamber.

\footnotetext{
* An earlier version of this article has benefitted from comments by the following individuals (listed alphabetically): Silke Hamann, Renate Raffelsiefen, Marzena Rochoń and Sabine Zerbian. All errors are my own.

${ }^{1}$ In this article I restrict my analysis to Modern Standard German (Krech et al. 1982, Drosdowski et al. 1990 , 1995 ) and to General American English (Kenyon \& Knot 1953), although I make some passing comments in the text to other varieties of these two languages.

The German and English examples like the ones in (1) bear a strong resemblance to the equivalent facts from Dutch (see Kager \& Zonneveld 1986 and Kager 1989). A question I consider worthy of further research is to investigate the extent to which the gencralizations established in the present article hold for all (West) Germanic languages.
} 
In the present article I discuss the distribution of trimoraic syllables in German and English. The reason I have chosen to analyze these two languages together is that the data in both languages are strikingly similar. However, although the basic generalization in (1) holds for both German and English, we will see below that trimoraic syllables do not have an identical distribution in both languages.

In the present study I make the following theoretical claims. First, I argue that the three environments in (1) have a property in common: they all describe the right edge of a phonological word (or prosodic word; henceforth pword). From a formal point of view, I argue that a constraint I dub the THIRD MORA RESTRICTION (henceforth TMR), which ensures that trimoraic syllables surface at the end of a pword, is active in German and English. According to my proposal trimoraic syllables cannot occur morpheme-internally because monomorphemic grammatical words like garden are parsed as single pwords. Second, I argue that the TMR refers crucially to moraic structure. In particular, underlined strings like the ones in (1) will be shown to be trimoraic; neither skeletal positions nor the subsyllabic constituent rhyme are necessary. Third, the TMR will be shown to be violated in certain (predictable) pword-internal cases, as in Monde and chamber; I account for such facts in an OptimalityTheoretic analysis (henceforth OT; Prince \& Smolensky 1993) by ranking various markedness constraints among themselves or by ranking them ahead of the TMR. Fourth, I hold that the TMR describes a concrete level of grammar, which I refer to below as the 'surface' representation. In this respect, my treatment differs significantly from the one proposed for English by Borowsky (1986, 1989), in which the English facts are captured in a Lexical Phonology model by ordering the relevant constraint at level 1 in the lexicon.

This article is structured as follows. $\$ 2$ consists of a short summary of the arguments presented in the literature on pwords in German and English. In $\$ 3$ I present examples from German and English illustrating the maximal size of the syllable. A formal treatment of these data is proposed in which the facts from both languages are analyzed as trimoraic. $\$ 4$ discusses the distribution of underlined strings as in (1) within grammatical words. Here I argue that the three contexts in (1) should be reduced to one, namely the right edge of a pword. The consequences my analysis has for the prosodic structure of affixed words are discussed in $\$ 5$. $\$ 6$ presents systematic exceptions to my analysis, i.e. trimoraic syllables that are internal to a pword, e.g. German Monde, English chamber. Here I argue that such data can be accounted for by ranking constraints referring either to syllable well-formedness or to paradigm uniformity. $\$ 7$ concludes.

\section{Evidence for the pword in German and English}

This section contains a brief discussion of the arguments for pwords in German and English and of the relationship between morphological structure and pwords in both languages. The 
material presented here will play a pivotal role in the analysis presented in the remainder of this article.

The pword is that constituent of the prosodic hierarchy larger than the foot but smaller than the phrase and is the smallest prosodic unit that must align with the edges of morphemes (see below). For studies of the pword in languages other than German and English see Dixon (1977a, b), Selkirk (1978), Booij (1983), van der Hulst (1984), Nespor \& Vogel (1986), McCarthy \& Prince (1986), Cohn (1989), Kang (1991), Prince \& Smolensky (1993), Hannahs (1995a, b) and Peperkamp (1997). A more in depth survey of the literature, and of the (crosslinguistic) arguments for pwords see Hall (1999a). A central claim made by all of the authors cited above is that the pword is not coterminous with the grammatical word; thus, it is uncontroversial that a single grammatical word can consist of two or more pwords (e.g. a compound word). Most, but not all, of the linguists cited above also believe that a single pword can consist of two or more grammatical words (e.g. a host + enclitic).

\subsection{German}

A number of linguists have argued that the pword plays a central role in German phonology and prosodic morphology, e.g. Booij (1985), Yu (1992a), Iverson \& Salmons (1992), Wiese (1996), Hall (1998, 1999b) and Raffelsiefen (2000). Although none of these authors agrees completely on how morphologically complex grammatical words should be parsed into pwords, there is a general consensus that the morphological configurations in the first column in (2) have the pword structure as indicated in the sample words in the second column. In (2) and below the pword is abbreviated as ' $\omega$ '.

(2)
(i) stem
(ii) stem+suffix containing no vowel
(iii) stem+vowel-initial suffix
(iv) stem+consonant-initial suffix
(v) prefix + stem

$\begin{array}{ll}(\text { lieb })_{\omega} & \text { 'love (imp. sg.)' } \\ (\text { lieb-t })_{\omega} & \text { 'love (3p.sg. ind. pres.)' } \\ (\text { lieb-e })_{\omega} & \text { 'love (lp.sg. ind. pres.)' } \\ (\text { lieb })_{\omega}-\text { lich } & \text { 'dearly' } \\ \text { ver-(lieb-t })_{\omega} & \text { 'in love' }\end{array}$

$(\text { lieb })_{\omega}$ 'love (inp. sg.)' 'love (3p. sg. ind. pres.)' 'dearly' in love'

(2) can be thought of for purposes of this ariticle as an algorithm which maps the morphological configurations in the first column into corresponding pword structure. From a formal point of view, the algorithm in (2) can be expressed in at least two different ways, e.g. a rule-based mapping (see Nespor \& Vogel 1986, Cohn 1989, Hannahs 1995a, b), or as an OT-based approach in which (alignment) constraints are utilized (see Selkirk 1995, Peperkamp 1997, McCarthy 2000). I assume the latter option here but do not formalize the constraints because they would detract from the issues discussed in the remainder of this article. At any rate the constraints that guarantee the parsings in (2) are undominated in 
German (and English, see $\$ 2.2$ ), i.e. their effects cannot be undone by higher ranked constraints.

Let us now consider $(2 \mathrm{i})-(2 \mathrm{v})$ in more detail. The parsings in (2i) and (2ii) are uncontroversial in the literature. The category 'stem' in (2i) subsumes monomorphemic words belonging to a major lexical category, i.e. noun, verb, adjective, adverb, preposition. By contrast, function words typically do not form their own pwords (see Hall 1999b for discussion). The status of bound stems that do not belong to lexical categories will be discussed in $\$ 6.5$. The category 'stem' is also intended to subsume each part of compound words, e.g. the word Bahnhof 'train station' is parsed (Bahn) $)_{\omega}(\text { hof })_{\omega}$. The pword structure indicated in (2ii) follows directly from the prosodic hierarchy: If the pword dominates the syllable, and if the suffix here is syllable-final, then it must also be final in the pword.

Several remarks concerning (2iii), (2iv) and (2v) are in order here. The crucial difference between (2iii) and (2iv) is that the suffix in the former configuration belongs to the same pword of the stem, whereas the suffix in the latter context does not. Following earlier writers, I refer to suffixes like $-e$ in (2iii) as 'cohering' and to ones like -lich in (2iv) as 'noncohering'. In (2iii) and (2iv) we see that the phonological shape of the suffix determines its status as cohering or noncohering: Vowel-initial suffixes are cohering and consonant-initial ones are noncohering. ${ }^{2}$ By contrast, all prefixes (see (2v)) are noncohering, regardless of their segmental composition or stress contour.

Although there is consensus that suffixes of the form $-\mathrm{CV}(\mathrm{C})$ like - lich in (2iv) are noncohering, there is some controversy involving whether or not they form their own pwords. With respect to $(2 \mathrm{v})$, there is agreement in the literature that stressed prefixes like un-, mit-, an- etc. are independent pwords, but there is no consensus concerning the status of unstressed prefixes, e.g. ver-, zer-, er-, and ent-. I return to these controversial issues in $\$ 5$.

A final remark needs to be made concerning the algorithm in (2). Since (2) maps either a single morpheme or a sequence of morphemes into pwords it is not possible for an arbitrary sequence of sounds within a morpheme to be an independent pword. This generalization is often implicit in rule-based work done on prosodic phonology (e.g. Nespor \& Vogel 1986) because the algorithms typically only refer to entire morphemes, as in (2). The same generalization is captured in OT-based frameworks with constraints aligning pwords with morphemes. I return to the question of whether or not an arbitrary sequence of sounds within a morpheme should enjoy the status of an independent pword in $\$ 6.5 .^{3}$

Three arguments that the pword is a constituent of German are presented in (3). (3i) and (3ii) are from Hall (1999b) and (3iii) is assumed in some form or another by certain writers (see below). The constraint MINIMALITY in (3i), familiar from other languages, also holds for

\footnotetext{
${ }^{2}$ It should be noted that -artig is an apparent exception, e.g. sand-artig 'sand-like'. All authors agree that -artig lies outside of the pword of the stem. See my comments on -artig in $\$ 4$ below.

${ }^{3}$ However, several studies implicitly challenge the claim that the pword cannot consist of an arhitrary sequence of sounds. See, for example, Wennerstrom (1993), Inkelas (1993), and Peperkamp (1997).
} 
German. The two phonotactic constraints in (3ii) bar various segments at the edge of or within a pword.

(3) (i) MinimaLity: The pword is minimally bimoraic

(ii) LAX VOWEl CONSTRAinT: * [ I Y $\varepsilon \propto u$ o ] ) $\omega$

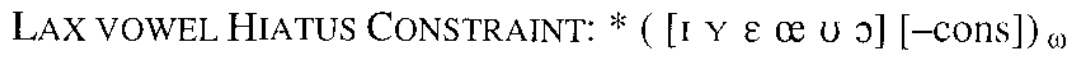

(iii) LAW OF INITIALS (LOI): In (...C.C...) $)_{\omega}$, CC does not occur word-initially.

Significantly, criteria (3i) and (3ii) together provide evidence that both stems (i.e. (2i)) and prefixes should be parsed as separate pwords, since no stem or prefix ends in [ $\mathrm{I} Y \varepsilon \propto u \diamond]$, nor does any stem or prefix have fewer than two moras. ${ }^{4}$ (3i) and (3ii) together also imply the parsings in (2iii) and (2iv), since the pwords in these structures are never subminimal, nor do they end in [ [ $\mathrm{I}$ Y $\varepsilon$ \& $U$ o].

A number of authors have argued that the domain of syllabification (in German, English and in other languages) is the pword, although the exact form of this rule/constraint varies from author to author (see Booij 1985, Yu 1992a, Wiese 1996, Hall 1998, Raffelsiefen 2000 for German). All of these authors have observed that a stem-final consonant syllabifies into the onset of a vowel-initial suffix but not into the onset of a consonant-initial suffix, even if the adjacent consonants otherwise occur syllable-initially, e.g. lieb-e [li..bə] in (2ii) vs. lieblich [li:p.lıç] in (2iii), cf. nebl-ig [ne:.blıç] 'foggy'. For purposes of this article I assume that the 'syllabification condition' refers to the LAW OF INITIALS in (3iii) (Vennemann 1972, Raffelsiefen 1999b for similar but not identical formulations). LOI is undominated in English and highly ranked in German (see $\$ 6.1$ for discussion).

\subsection{English}

In contrast to German, there is little consensus concerning the pword structure in English (see Aronoff \& Sridhar 1983, Booij \& Rubach 1984, Raffelsiefen 1993, Wennerstrom 1993, McCarthy 1993, and Raffelsiefen 1999a, 1999b for various approaches).

Following Raffelsiefen's (1999b) treatment of English word formation, we can postulate that the algorithm in (2) for German is essentially the same for English. Thus, monomorphemic words $(=(2 \mathrm{i}))$ and sequences of stem+suffix containing no vowel $(=(2 \mathrm{ii}))$ parse into separate pwords, e.g. (love) $)_{\omega}$, (love-s) $)_{\omega}$. Several arguments (one of which will be presented below) suggest that vowel-initial suffixes of English have the cohering representation in (2iii), and that consonant-initial ones have the noncohering one in (2iv), e.g.

\footnotetext{
${ }^{4}$ This generalization holds only for prefixes which contain full (i.e. unreduced) vowels because German also has the two prefixes ge- $[\mathrm{g}$ ol and be- [bə] (see $\$ 5$ below). Since no pword contains a schwa as the only vowel these prefixes are not separate pwords. One exception to the gencralization that stressed prefixes are always bimoraic is a- [a], e.g. agrammatisch 'agrammatical' (sec Hall 1999b and Raffelsiefen 2000).
} 
(pimpl-ous) $)_{\omega}$, (rump) $)_{\omega}$ less. Arguments that English prefixes are noncohering, as in $(2 \mathrm{v})$, are presented in Raffelsiefen (1999a).

One argument that for the distinction between the cohering structure in (2iii) and the noncohering one in (2iv) is syllabification, i.e. the LOI in (3iii). As a representative example, consider the following words in (4) (from Raffelsiefen 1999b). The first word contains a stem + vowel-initial suffix and the second one a stem + consonant-initial suffix.

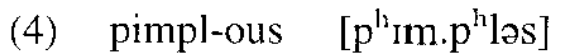 \\ rump-less [x $\left[\mathrm{mp}^{2}\right.$.los]}

According to Kahn (1976) the /p/ is aspirated in a word like pimpl-ous and (optionally) unreleased and glottalized in an example like rump-less; this suggests alternate syllabifications, i.e. the $/ \mathrm{p} /$ in the former word is syllable-initial and in the latter word syllable-final. The LOI, which as mentioned above is undominated in English, would be violated in the second form in (4) if this were a single pword, since many English words begin with /pl/. That the parsing [.I $\mathrm{mp}^{\text {? }}$.ləs] violates the LOI can be explained if this word has the noncohering representation mentioned above.

\section{Syllable and moraic structure}

In $\$ 3.1$ I discuss the syllable structure of German and English words like the ones in (1) and present a new proposal in which I account for the maximal syllable in both languages in terms of moraic structure. In $\$ 3.2 \mathrm{I}$ compare my approach with other previous ones.

\subsection{A new proposal}

The following German and English words have been divided into three categories based on the structure of the 'rhyme' part of the syllable. In (5a) it consists of a short vowel plus two consonants, in (5b) a long vowel plus a single consonant and in $(5 \mathrm{c})$ a diphthong plus a single consonant. All relevant strings in (5) and below have been underlined.

(5a) short vowel+two consonants

\begin{tabular}{|c|c|}
\hline kalt & 'cold' \\
\hline Kalb & 'calf' \\
\hline krank & 'sick' \\
\hline plump & 'awkward' \\
\hline
\end{tabular}

(5b) long vowel+one consonant

$\begin{array}{lll}\text { viel } & \text { 'much' } & \text { doom } \\ \text { Lob } & \text { 'praise' } & \text { root } \\ \text { R } \underline{\text { ahm }} & \text { 'cream' } & \text { seem }\end{array}$


(5c) diphthong+one consonant

$\begin{array}{lll}\text { Zeit } & \text { 'time' } & \text { hike } \\ \text { B } \underline{\text { aum }} & \text { 'tree' } & \text { house } \\ \underline{\text { euch }} & \text { 'you (2p.pl. acc.)' } & \text { noise }\end{array}$

Some cooccurrence restrictions govern the vocalic element(s) and the final consonant(s) in words like the ones in (5), but in general the final consonant is not restricted with respect to place of articulation, i.e. it can be labial, dorsal, or coronal.

A number of writers (see below) have observed that syllables like the ones in (5) can only be followed by coronal obstruents. Some representative examples have been presented in (6). The words in (6a) include a single coronal obstruent to the right of underlined strings like the ones in (5) and the ones in (6b) include two coronal obstruents. All relevant coronals have been underlined.

\begin{tabular}{|c|c|c|c|}
\hline$(6 a)$ & Mond & 'moon' & fiend \\
\hline & Freund & 'friend' & find \\
\hline & Feind & 'enemy' & sound \\
\hline & Haupt & 'chief' & count \\
\hline & Markt & 'market' & pounce \\
\hline & Fuchs & 'fox' & launch \\
\hline & Krebs & 'cancer' & lounge \\
\hline & film-t & 'film (3p.sg.)' & film-ed \\
\hline & feil-sch & 'bargain (imp. sg.)' & pond-s \\
\hline & Wurf-s & 'litter (gen. sg.)' & six-th \\
\hline (6b) & Herbst & 'autumn’ & find-s \\
\hline & hilf-st & 'month (2p. sg. ind.)' & pounce-d \\
\hline & feilsch-st & 'bargain (2p. sg.)' & \\
\hline
\end{tabular}

Note that the final coronal obstruent(s) can either be tautomorphemic with the preceding segments, as in the first seven German and English pairs in (6a), or they can belong to a separate morpheme. Both German and English seem to prefer no more than two coronal obstruents after underlined strings like the ones in (6). ${ }^{5}$

My analysis of the data in (5) and (6) relies on the assumption that the only elements intervening between the segments and the syllable node is the mora; hence, there are neither

\footnotetext{
5 The pronunciation of the genitive singular of Herbst 'autumn' and Obst 'fruit' as Herbsts and Obstes suggests that German allows up to three coronal obstruents after a $\mathrm{VCC}$ or $\mathrm{V}: \mathrm{CC}$ sequence. However, some linguists have noted that the preferred pronunciation for these words is with [əs], i.e. Herbstes and Obstes (see Vennemann 1982: 299, Wiese 1988: 101, footnote 21). The only other German example 10 my knowledge with three coronal obstruents following a VCC or V:CC sequence is the final word in (6b).
} 
skeletal positions nor traditional subsyllabic constituents, e.g. onset, rhyme (see Hyman 1985, McCarthy \& Prince 1986, Hayes 1989, Zec 1995 for similar proposals regarding syllable and mora geometry). Onset consonants link directly to the syllable node and nuclear and coda consonants to the mora (cf. Hayes 1989), as illustrated in the sample representations for the four words den, bee, lie and relay in (7):

(7)

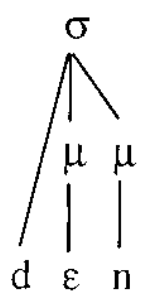

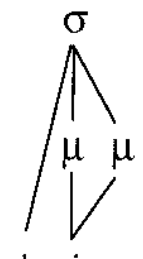

b i:

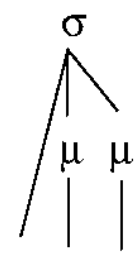

I a I

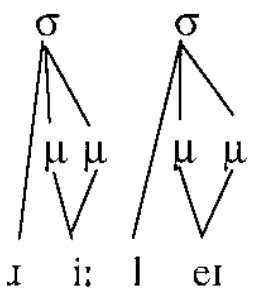

The moraic portion of the syllables in (7) consists of either (i) a short vowel + one consonant, (ii) a long vowel, or (iii) a diphthong. All of the syllables in (i)-(iii) are identical in the sense that they are bimoraic.

An important ingredient in my analysis is that the maximal syllable of German and English contains exactly three moras (see Féry 1995, 1997 for a similar proposal for German). From a formal point of view, I propose that both German and English have the following template for the maximal syllable:

(8) The maximal syllable of German and English:

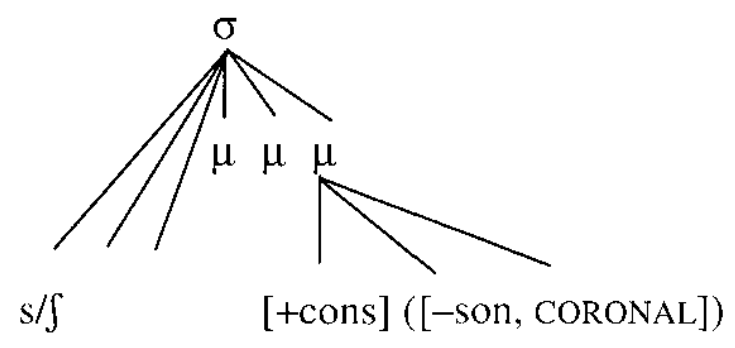

The structure in (9) says that the syllable dominates maximally three moras, where the third one is always linked to a single consonant and optionally to two coronal obstruents. ${ }^{6}$ The syllable can begin with a maximum of three segments, the first of which is [s] or [s].

Sample structures for the three words elm, feel and line, which are representative of the examples in (6), have been presented in (9). In these words the final consonant is linked directly to the third mora:

\footnotetext{
${ }^{6}$ In some varieties of American English (including my own) consonants other than coronal obstrucnts can surface after [0:I], e.g. fork, absorb, form, etc. (see Hammond 1999). I have no explanation for why [o:I] is the only sequence of long vowel plus consonant, after which a noncoronal obstruent can appear. For purposes of this article I assume that [O:I] is (exceptionally) bimoraic, i.e. [o:] is linked to two moras and [I] to the second of these moras. Given the bimoraic sequence [o:I], noncoronal obstruents can follow because they do not violate the template in (8). In \$6.3 I argue that other sequences of VCC in English arc exceptionally bimoraic.
} 
(9)

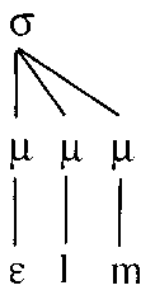

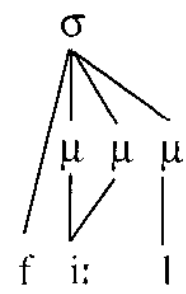

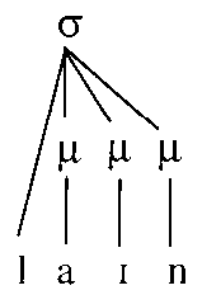

It should be noted that some versions of moraic theory impose an upper limit of two moras per syllable and only invoke trimoraic syllables under marked circumstances (see, for example, Hayes 1989). Three languages in which trimoraic syllables have been argued to exist include Komi, Hindi and Estonian (see Hayes 1989, Kenstowicz 1994: 430-431), and in the Germanic family Proto-Germanic (Hayes 1989), Dutch (Kager 1989), the Dithmarschen/Staudenhagen dialect of German (Hock 1986, Hayes 1989), and Standard German (Féry 1995, 1997). ${ }^{7}$

Consider now the representation for texts in (10a), which is representative of the words in (6). This example illustrates that the final mora can dominate up to three consonants, the final two of which are coronal obstruents (= the maximal expansion under the third mora in (8)).

(10a)

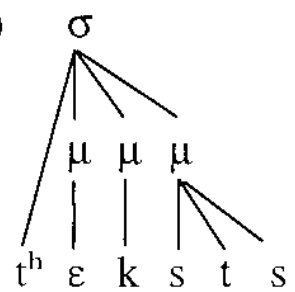

$(10 b)$

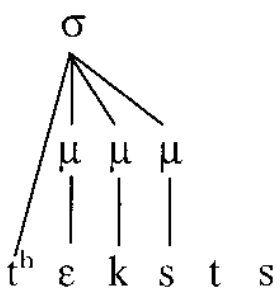

An important aspect of my analysis is that final coronal obstruents like the ones in (6) are linked directly to the third mora. This treatment is clearly at odds with the often assumed alternative view that final coronal obstruents are 'stray' in the sense that they are situated outside of the syllable, as in (10b). For analyses in which such stray coronals are presupposed see Wiese (1988: 99-102, 1991: 114ff.), Yu (1992b: 174), Wiese (1996: 47-49; 55-56) and Grijzenhout (1998: 31-32) for German; Kiparsky (1981: 253-255), Borowsky (1986: 180ff.), Giegerich (1992b: 144ff.), and Kenstowicz (1994: 259-261) for English. Representations like the one in (10a) are the crucial difference between the present proposal and the one made for Standard German by Féry $(1995,1997)$, who assumes that final coronals are stray, as in $(10 \mathrm{~b}){ }^{8}$

\footnotetext{
${ }^{7}$ Féry $(1995,1998)$ argues that her equivalent of the moraic representations in (9) derives support from German word stress, which refers to quantity. For an earlier (nonmoraic) treatment in which German word stress is held to be quantity-sensitive see Giegcrich (1985). By contrast, Wiese (1996) argues that the German word stress rule is not quantity-sensitive.

${ }^{8}$ In several current studies it has been proposed that stray consonants like the ones in (10b) are linked to a higher constituent in the prosodic hierarchy, e.g. the pword or the foot. See, for example, Rubach (1997) and Rochon (2000: 130-135) for Polish and Green (2000) for Attic Greek and Munster Irish.
} 
The analysis contained in the present article is based on the presupposition that the maximal syllable template in (8) - as well as the generalization I posit in (12) below which accounts for their distribution - are surface representations and not abstract representations that exist at an early stage in the derivation. The reason the analyses cited in the preceding paragraph with stray coronal obstruents require abstract syllables is that they typically presuppose a rule of 'stray segment adjunction' that associates the stray segment(s) in (10b) with the syllable at a later stage in the derivation. ${ }^{9}$ Linguists who posit a rule of stray segment adjunction include Wiese (1991: 123-124), Yu (1992a: 29, 1992b: 175), Wiese (1996: 56) for German and Kiparsky (1981: 254), Borowsky (1986: 179-180), Kenstowicz (1994: 258-261) for English. The reader is referred to Fudge (1969: 265ff.), Spencer (1996: 98-100), Roca \& Johnson (1999: 286ff.) and Hall (2000) for analyses of English in which final coronal obstruents as in (7) are analyzed as belonging to the syllable and not as 'stray', as in (10b).

I assume that short and long vowels are associated with the respective moraic structures in the underlying representation but that postvocalic moras are derived by the constraints (i)-(iii) in (11a). The constraint WEIGHT BY POSITION (WBP) (see Hayes 1989) guarantees that a syllable-final consonant following a short vowel is dominated by its own mora and $3-\mu$ that a syllable-final consonant or consonants following two moras is dominated by a third mora. Independent phonotactic constraints predict that the second and third consonants under the third mora are coronal consonants. DEP- $\mu$ is the constraint that prohibits the insertion of a mora. The language specific ranking for German and English is presented in (11b).

(11a) (i) WBP: A syllable-final consonant following a short vowel is moraic

(ii) 3- $\mu$ : A syllable-final consonant or sequence of consonants following two tautosyllabic moras is moraic

(iii) DEP- $\mu$ : No insertion of a mora.

(11b) WBP, $3-\mu \gg$ DEP- $\mu$

The ranking WBP » DEP- $\mu$ ensures that words like the ones in (7) are parsed as indicated. The ranking $3-\mu$ »DEP- $\mu$ guarantees the parsings in (9) and (10a). I show below in $\$ 6$ that for English (but not for German) $3-\mu$ is dominated by two other constraints.

The advantage of analyzing the maximal syllable of German and English as trimoraic is that this representation allows one to make a simple and straightforward statement concerning the distribution of underlined strings like the ones in (5) within grammatical words. In contrast to bimoraic syllables like the ones in (7), syllables dominating three moras, as in (9), have a restricted occurrence in the sense that (generally speaking) they cannot surface morpheme-

\footnotetext{
${ }^{9}$ In placing an emphasis on the surface representation I have been influenced not only by recent work done in Optimality Theory (Prince \& Smolensky 1993), but also by earlier work done on Natural Phonology (Stampe 1973), Natural Generative Phonology (Hooper 1976) and approaches to language change (c.g. Vennemann 1988).
} 
internally, e.g. monomorphemes like *areelba and *agelmda do not occur. In $\$ 4$ I discuss the distribution of trimoraic syllables in detail and conclude that their occurrence should be accounted for by referring to the pword, as I noted in $\$ 1$ above. The proposal I defend in that section is encapsulated in the constraint in (12):

\section{THIRD MORA RESTRICTION (TMR):}

The third mora only surfaces at the end of a pword.

I assume for purposes of this article that the TMR is a 'primitive' constraint, although it would be possible to replace it with an alignment constraint stating that the right edge of a trimoraic sequence aligns with the right edge of a pword. Nothing in my analysis crucially requires the second option. ${ }^{10}$

\subsection{Alternative proposals}

An obvious alternative to the template in (8) and to representations like the ones in (9) and (10a) is one in which reference is made not to moras, but instead to skeletal positions and/or traditional subsyllabic constituents, i.e. the rhyme. In this section I discuss various options along these lines that have been proposed in the literature for English and German, as well as one alternative that has to my knowledge not been explicitly stated in print, and show that they are all inferior to the moraic approach I outlined in the previous subsection.

Based on an earlier study by Moulton (1956), Wiese (1988) argues that the German facts presented in $\$ 3.1$ can be explained by referring to the number and type of skeletal positions within a syllable. Specifically, he argues that the German syllable has the maximum form in (13a), i.e. a single $\mathrm{V}$ slot preceded and followed by two $\mathrm{C}$ positions respectively. The template in (13a) is also accepted in Wiese's later publications (e.g. Wiese 1991, 1996).

(13a)

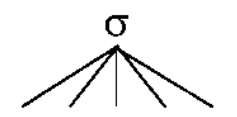

$\mathrm{C} \mathrm{C} \mathrm{V} \mathrm{C}$ (13b)

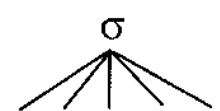

$\mathrm{C} \mathrm{C} \mathrm{V} \mathrm{C} \mathrm{C}$

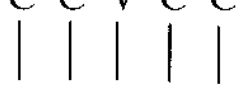

k R a $\mathrm{g}$ k
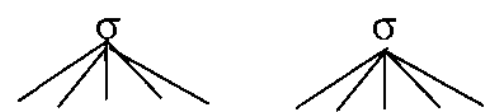

$\mathrm{C} \mathrm{C} \mathrm{V} \mathrm{C} \mathrm{C} \mathrm{C} \mathrm{C} \mathrm{V} \mathrm{C} \mathrm{C}$

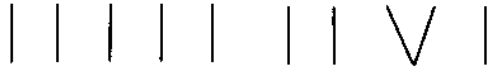

$\mathrm{t} \quad \mathrm{R} \quad \mathrm{a} \quad \mathrm{u} \mathrm{m} \quad \mathrm{g} \mathrm{n} \quad \mathrm{O}: \mathrm{m}$

The 'maximal' syllable (Wiese 1996)

Sample representations of the three German words krank 'sick', Traum 'dream', and Gnom 'gnome' consisting of the maximum syllable in Wiese's model in (13a) have been presented

\footnotetext{
${ }^{10}$ One might assume that three segment onsets (e.g. German Straße English street) surface only in pword-initial position - a treatment that would require that VsCCV be parsed Vs.CCV in words like astrology. The reason I assume that $\mathrm{VsCCV}$ is parsed $\mathrm{V} . \mathrm{sCCV}$ (and therefore that $\mathrm{sCC}$ can surface pword-internally) is that the stop following [s] is unaspirated.
} 
in (13b). Note that Wiese's treatment requires long vowels to be analyzed structurally as VC and not as VV as is commonly assumed (e.g. Clements \& Keyser 1983).

Mouton (1956) and Wiese (1988, 1996) observe correctly that trimoraic structures (= the VCC part of (13a)) can only be exceeded by coronal obstruents (see (6)). The latter author concludes that since there is no slot for such consonants in template (13a), that they are situated outside of the syllable. " A representative example for the German word Mond is provided in (14):

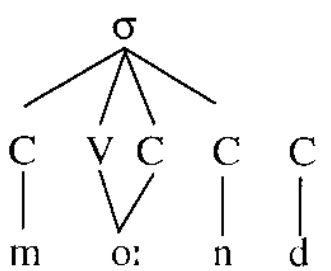

I reject analyzing the maximal rhyme of German (or English) as VCC, as in (13a), for two reasons. First, the structure in (14a) does not describe a surface syllable of German. The reason the structure in (14) is an abstract syllable and not a surface syllable is that the wordfinal coronal obstruents like the one in (14) undergo Final Devoicing (= [mo:nt]). Since Final Devoicing affects syllable-final obstruents ${ }^{12}$ the 'stray'/d/ in a word like the one in (14) must be linked up with the syllable at a later stage in the derivation (see Hall 1992: 124-126 for a rule-based approach of German in which these sequences of steps is made explicit). An advantage of the present proposal is that the template in (9) holds for the surface representation and does not require reference to an abstract stage in a derivation.

The second reason I reject an analysis in which the maximal rhyme is VCC, as in (13a), is that it does not allow the TMR in (12) to be stated in an satisfactory way. Thus, assuming the template in (13a), one could only describe the part of the syllable with a restricted distribution as 'VCC plus following coronal obstruents', but neither 'VCC', nor 'VCC plus coronal obstruents' form a constituent in (13). By contrast, the moraic model I sketched in the preceding section allows one to describe the part of the syllable that has a restricted distribution in a unified way, namely the third mora.

A conceivable alternative to the one in (13a) is a template in which the subsyllabic constituent 'rhyme' mediates between the skeletal tier and the syllable node. An analysis

\footnotetext{
11 Wiesc makes a similar generalization concerning the onset (= the first two C positions in (13a)): Two-member onsets can be preceded by [s $\left.\int\right]$, which must be located outside of the syllable because they do not fit into template (13a).

${ }^{12}$ Considerable discussion in the literature has been devoted to the environment of German Final Devoicing (see, for example, Vennemann 1972, Wurzel 1980, Hall 1993, Brockhaus 1995 and Wicse 1996 and references cited therein). A commonly assumed alternative to the syllable final environment is that all obstruents are devoiced within a subsyllabic constituent (e.g. coda, rhyme, mora).
} 
along these lines might analyze the maximal rhyme of German and English as in (15a). Sample representations of the three English words elm, feel and line are presented in (15b):

(15a) The maximal rhyme of English: (15b)

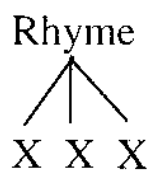

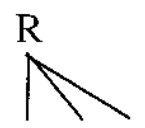

$\mathrm{X} \times \mathrm{X}$

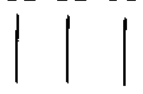

$\varepsilon 1 \mathrm{~m}$

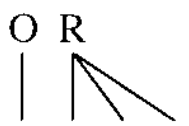

$\mathrm{X} X \mathrm{X} \mathrm{X}$

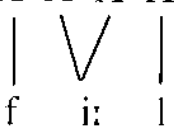

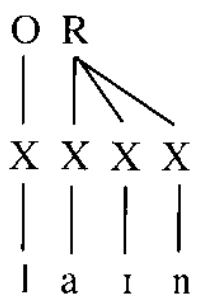

Giegerich (1992b: 144ff.) assumes the maximal rhyme structure in (15a) for English. ${ }^{13}$ Giegerich argues that a three member rhyme of English can only be exceeded by coronal obstruents (see (7)) and concludes that the final coronals in words like texts are therefore situated outside of the rhyme at the point in the derivation where (15a) holds. A typical representation for this abstract stage (see Giegerich 1992b: 148) is provided in (16):

(16)

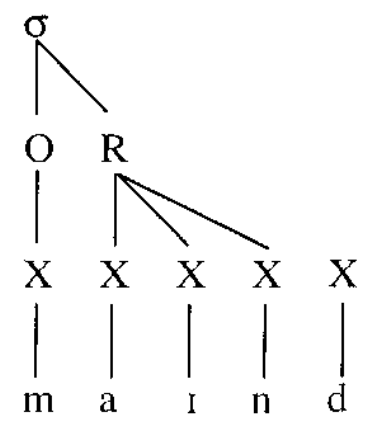

The template in (15a) is subject to the same two criticisms that were levelled against the $\mathrm{CV}$ template in (13a). First, (15a) is an abstract syllable and not a surface syllable. The reason the syllable in (16) cannot be correct for the surface is that the final voiceless coronal stop in English words like pint undergoes the rule of Glottalization to $\left[\mathrm{t}^{2}\right]$. Since Glottalization holds syllable finally (see Kahn 1976: 84ff., Withgott 1982: 165-169, Gussenhoven 1986, Nespor \& Vogel 1986: 77-78, Giegerich 1992b: 220-221, Kenstowicz 1994: 69), the implication is that this segment cannot be situated outside of the syllable on the surface.

The second criticism of (15a) is that the part of the syllable that has a restricted distribution, i.e. the 'rhyme plus coronal obstruents', is not a constituent. Assuming for the sake of argument that there is a surface based template similar to the one in (15a) in which final coronal obstruents are linked directly to the rhyme, as in (17), one could still not adequately describe the part of the syllable that has a limited distribution:

\footnotetext{
${ }^{13}$ See also Kiparsky (1981), Borowsky (1986: 146) and Kenstowicz (1994: 259fi.), who presuppose a template very similar to the one in (15a) which they express in alternative representational models.
} 
(17)

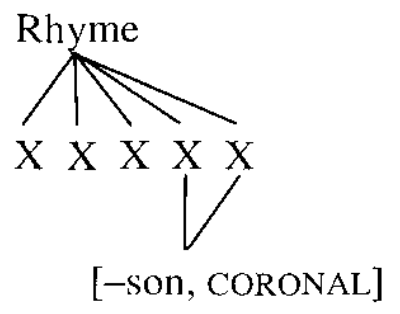

Given (17), one would be forced to say that the part of the syllable that has a restricted distribution is 'a rhyme consisting of three skeletal slots or more', but this sequence is not a constituent.

\section{The distribution of trimoraic syllables}

In this section I present data from English and German illustrating the distribution of trimoraic structures within grammatical words. An important goal in the following paragraphs is to demonstrate the validity of the TMR in (12).

Consider first the distribution of the bimoraic syllables in den, bee, lie and relay, cf. the representations in (7), which I repreat in (18) for convenience:
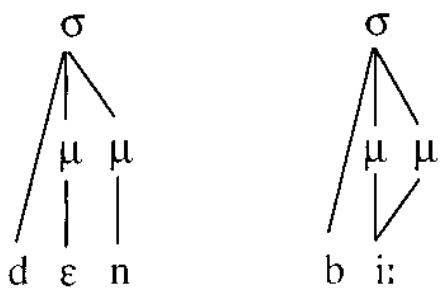

b i:
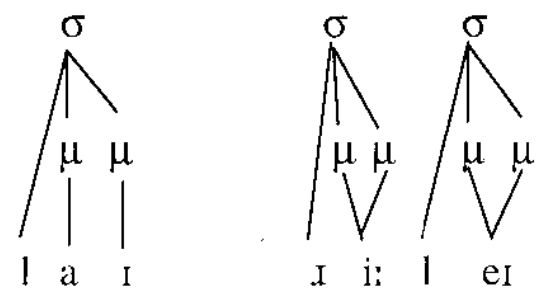

The words in (19) below all contain such bimoraic syllables. These words have been organized into one of four separate categories. All relevant bimoraic structures in these examples have been underlined. The first three environments together can be categorized as 'morpheme-final position', i.e. word-finally in (19a), before a compound boundary in (19b) and before a suffix in (19c). The fourth context is illustrated in (19d). These words show that bimoraic syllables also surface 'morpheme-internally', i.e. the bimoraic syllable and the following segment(s) are tautomorphemic.

(19a) Bimoraic syllables word-finally:

$\begin{array}{ll}\text { See } & \text { 'sea' } \\ \text { Tuㅡ } & \text { 'dew' } \\ \text { Bett } & \text { 'bed' }\end{array}$


(19b) Bimoraic syllables before a compound boundary:

See-tang 'sea-weed'

Schuh-anzieher 'shoe-horn'

Blick-kontakt 'eye-contact'

(19c) Bimoraic syllables before a suffix:

Droh-ung 'threat'

schuh-Ios 'shoe-less'

Frei-heit 'free-dom'

männ-lich 'man-ly'

(19d) Bimoraic syllables morpheme-internally:

Balalaika 'balalaika'

Konferenz 'conference'

Filter 'filter'

Let us now consider the distribution of trimoraic syllables. The data in (20) below have been organized into three separate contexts: (i) before a word boundary in (20a), (ii) at the end of each part of a compound in (20b) and (iii) before a consonant-initial suffix in $(20 \mathrm{c})$, i.e. before a suffix of the form $-\mathrm{CV}(\mathrm{C})$. In all three contexts trimoraic syllables surface freely.

(20a) Trimoraic syllables in word-final position:

$\begin{array}{lll}\text { Werk } & \text { 'work' } & \underline{\text { arm }} \\ \text { Zeit } & \text { 'time' } & \underline{\text { loud }} \\ \text { B } \underline{\text { aum }} & \text { 'tree' } & \underline{\text { eel }} \\ \text { Buch } & \text { 'book' } & \text { height }\end{array}$

(20b) Trimoraic syllables before a compound boundary:

Werk-statt 'workshop' $\underline{\text { arm-chair }}$

Zeit-geist 'Zeitgeist' loud-mouth

Baum-stamm 'tree trunk' work-shop

Buch-weizen 'buckwheat' height-assimilation

(20c) Trimoraic syllables before a $C V(C)$ suffix:

$\begin{array}{lll}\text { fünf-zig } & \text { 'fifty' } & \text { doubt-ful } \\ \text { leb-los } & \text { 'lifeless' } & \text { fear-less } \\ \text { Ein-heit } & \text { 'unit' } & \text { appease-ment } \\ \text { lieb-lich } & \text { 'dearly' } & \text { part-ly }\end{array}$

The following words all illustrate that trimoraic syllables in the three contexts in (20) can be augmented by final coronal obstruents: 
(21a) Trimoraic syllables (including coronal(s)) in word-final position:

$\begin{array}{lll}\text { Mond } & \text { 'moon' } & \text { sound } \\ \text { Herbst } & \text { 'autumn' } & \text { sixth } \\ \text { Obst } & \text { 'fruit' } & \text { text }\end{array}$

(21b) Trimoraic syllables (including coronal(s)) before a compound boundary:

$\begin{array}{lll}\text { Haupt-mann } & \text { 'captain' } & \text { sound-wave } \\ \text { Markt-platz } & \text { 'market place' } & \text { launch-pad } \\ \text { Obst-garten } & \text { 'fruit garden' } & \text { text-book }\end{array}$

(21c) Trimoraic syllables (including coronal(s)) before a CV(C) suffix:

$\begin{array}{lll}\text { Freund-schaft } & \text { 'friendship' } & \text { bound-less } \\ \text { Pünkt-chen } & \text { 'little dot' } & \text { mind-ful } \\ \text { herbst-lich } & \text { 'autumnal' } & \text { sound-ly }\end{array}$

There is one significant difference between the bimoraic syllables in (19) and the trimoraic ones in (20) and (21), namely, trimoraic syllables are absent morpheme-internally, i.e. when tautomorphemic with the following segment(s). This gap is illustrated with three nonce forms in the first column of (22). The occurring words in the right column illustrate that bimoraic syllables can surface in a similar environment (see also (19d)):

$$
\begin{array}{ll}
\text { No trimoraic syllables morheme-internally: } \\
\begin{array}{ll}
\text { *areel.ba } & \text { (cf. are.na) } \\
\text { *agelm.da } & \text { (cf. agen.da) } \\
\text { *laim.da } & \text { (cf. balalai.ka) }
\end{array}
\end{array}
$$

While the basic generalization in (22) is correct, I show below in $\$ 6$ that under certain completely predictable circumstances a syllable ending in VCC or V:C can occur morphemeinternally, as in (22).

Let us now consider environment (20c) and (21c). Since the examples presented there only include consonant-initial suffixes it is important to consider the status of trimoraic syllables before vowel-initial syllables. That trimoraic syllables are typically barred from occurring in this environment is a consequence of syllabification, as illustrated in the German examples in (23). These words consist of a stem + vowel-initial suffix, where the bare stem ends in a trimoraic sequence. An examination of the phonetic forms in (23) reveals that the final syllable of the stem is bimoraic, since the stem-final consonant(s) are syllable-initial:

(23) Bimoraic rhymes before a $V(C)$ suffix:

$\begin{array}{lll}\text { lieb-e } & \text { [li..bə] } & \text { 'love (1p.sg. ind. pres.)' } \\ \text { erb-en } & \text { [Ee.bən] } & \text { 'inherit (inf.)' }\end{array}$


It should be noted here that the parsings in the phonetic forms in (23) are uncontroversial in the literature on German phonology because they can be motivated by language specific arguments. In this case, since the /b/ both liebe and erben do not undergo Final Devoicing we can safely conclude that they are syllable-initial and not syllable-final. In the final example /R/ surfaces as [e]. Since r-vocalization uncontroversially takes place in coda position (see Giegerich 1989: 47ff., Hall 1992: 56-58, 1993: 88ff., Wiese 1996: 256ff.) the implication is that a word like erben is parsed /VR.bV/. ${ }^{14}$

Consider now the German examples in (24), which consist of a stem + artig. -artig is unique in that it does not alow a stem-final consonant to be in the onset, as indicated in the phonetic representations.

$\begin{array}{lll}\text { sand-artig } & \text { [zant.aetıç] } & \text { 'sand-like' } \\ \text { zwerg-artig } & \text { [tsvevk.aetıç] } & \text { 'dwarf-like' } \\ \text { baum-artig } & \text { [baum.aetıç] } & \text { 'tree-like' } \\ \text { krebs-artig } & \text { [kRe:ps.aetıç] } & \text { 'crab-like' }\end{array}$

That trimoraic syllables precede the suffix -artig is therefore simply a consequence of the fact that the stem-final consonant is not situated in onset position. Due to the syllabification data in (24) there is agreement in the literature that -artig does not belong to the same pword as the stem to which it attaches (see note 2). This can be captured formally by saying either (i) - artig is associated underlyingly with a pword, or (ii) -artig is a stem and hence gets parsed as an independent pword by (3i) (see Hall 1992: 105-106, Wiese 1996: 65, footnote 32, and Raffelsiefen 1999b: 272, who take the second option). I assume here that (ii) is correct.

The contexts in which trimoraic syllables occur are summarized in (25a) and the one environment in which they are barred from appearing in (25b) with two nonce words.

(25a) Three contexts in which trimoraic syllables occur: context

(i) before a word boundary

(ii) before a compound boundary

(iii) before suffixes of the form $-\mathrm{CV}(\mathrm{C})$
German

Werk

Werk-statt

lieb-lich
English

$\underline{\operatorname{arm}}$

arm-chair

event-ful

(25b) One context in which trimoraic syllables cannot occur:

context

(i) morpheme-internally

\section{German}

*areel.ba

\section{English}

*areel.ba

\footnotetext{
${ }^{14}$ As I note in $\$ 6.1 .2$ below there is no consensus in the literature on English phonology that corresponding English words (c.g. arriv-al, help-ing) are syllabified as in (23), i.e. [ə.rar.val], [hel.pIn]. As I point out in that section many analysts have argued that codas in such words are maximized, c.g. [help.in] (sce, for example, Selkirk 1982, Hammond 1999). See below for further discussion.
} 
The analysis of pwords presented in $\$ 2$ enables us to reduce the three contexts in (25a) to one: pword-final position. In all of these examples the underlined sequence is in situated at the right edge of a pword based on the algorithm with maps morphological structure into pwords in (2). Thus, (2i) predicts that Werk and arm are single pwords, that Werkstatt and armchair consist of two and that -lich and -ful do not belong to the pword of the stem lieb and event.

Consider now the gaps in (25b). The nonexistence of morpheme-internal trimoraic syllables follows directly from the algorithm presented in (2) above. Step (2i) guarantees that every (monomorphemic) stem be assigned a single pword. Monomorphemic words like *ageenda and *agelmda are automatically ruled out because the pword cannot 'split' a morpheme, i.e. the pword consists either of a single morpheme or more than one morpheme.

Recall from (2ii) that a string consisting of stem + vowel-initial suffix has a cohering representation, i.e. one in which the stem and suffix are mapped into a single pword. Given this parsing, one would not expect to find trimoraic structures in the corresponding stem, e.g. in a hypothetical word like $*$ (areel.b-ing) $)_{\omega}$, since they are not situated in pword-final position. In fact, the nonoccurrence of most trimoraic syllables in this context can be attributed to the nonexistence of the corresponding stems, e.g. *areelb-ing is nonoccurring because *areelb violates the template in (9). As I show below in $\$ 6$, many German and English words do indeed exist in which a trimoraic syllable is situated in the stem in stem + vowel-initial suffix (e.g. German $M \underline{o n} d-e$ ), but they are completely systematic, i.e. there is an independent reason why the trimoraic syllable occurs in this context.

\section{The pword structure of affixed words}

The proposal sketched in $\$ 3$ and $\$ 4$ makes concrete predictions concerning the prosodic structure of affixed words. I begin this section by considering suffixation and conclude with prefixation.

The prosodic structure (i.e. moras, syllables, feet, and pwords) of affixed words in German and English is an extremely broad topic with ramifications for other aspects of the phonology and morphology of these two languages. The purpose of the present section is to apply the TMR as a diagnosic for pword structure of affixed words and to show how it does or does not correlate with other diagnostics for pwordhood proposed by other linguists.

\subsection{Suffixed words}

The German words in the second column of (26) consist of stems ending in a trimoraic syllable followed by the corresponding suffix in the first column. Note that all of the suffixes in (26) are consonant-initial and trimoraic. Recall from (2iv) that consonant-initial suffixes like the ones in (26) are noncohering; that is, they are not integrated into the same pword as the stem to which they attach. 


$\begin{array}{lll}\begin{array}{ll}\text { suffix } \\ \text {-schaft }\end{array} & \text { example } & \\ \text {-heit } & \text { Freundschaft } & \text { 'friendship' } \\ \text {-haft } & \text { krankhaft } & \text { 'cowardice' } \\ \text {-bar } & \text { lesbar } & \text { 'readable' } \\ \text {-lein } & \text { Häuslein } & \text { 'house (dim.)' } \\ \text {-los } & \text { leblos } & \text { 'lifeless' } \\ \text {-sam } & \text { schweigsam } & \text { 'silent' } \\ \text {-tum } & \text { Reichtum } & \text { 'riches' }\end{array}$

Since both the stem and suffix must be final in a pword I adopt the representation in (27) for these words. In (27) the stem and suffix are dominated by a separate foot (= F in (27) and below) to capture the generalization that the stem is primarily stressed $\left(=F_{s}\right)$ and the suffix secondarily stressed $\left(=\mathrm{F}_{\mathrm{w}}\right) \cdot{ }^{15}$ Both feet in $(27)$ are dominated by separate pwords.

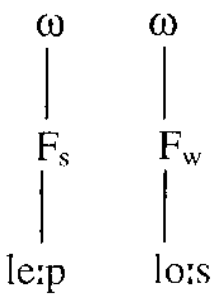

The representation in (27) - in particular the pword dominating the suffix - derives additional support from the fact that rule predicting the relative prominence within the constituents of a suffixed word makes direct reference to the pword (Raffelsiefen 2000). ${ }^{16}$

In contrast to German, there are apparently no noncohering suffixes of English that bear secondary stress which would have a representation like the one in (27) (see Raffelsiefen 1993: 102ff., 1999b: 254ff.). ${ }^{17}$ The following German and English examples consist of a stem ending in a trimoraic syllable plus a (noncohering) consonant-initial suffix containing a reduced vowel (=schwa).

\footnotetext{
${ }^{15}$ There is general agrecment in the literature that suffixes like the ones in (26) are secondarily stressed (see, for example, Kiparsky 1966, Rcis 1974, Giegerich 1985, Eisenberg 1991, Hall 1998, Raffelsiefen 2000). By contrast, Wiese (1996) does not postulate secondary stress for the suffixes in (26). See Hall (1998) for criticisms of Wiese's approach.

${ }^{16}$ I leave open the nature of the prosodic constituent that dominales the two pwords in (27).

${ }^{17}$ As Raffelsiefen (1999b: 255) notes, vowel reduction in certain noncohering suffixes of English is blocked by various phonological conditions, e.g. -hood, -like, -wise, -fold, -most. She argues that these suffixes are dominated by their own feet but not by their own pwords.
} 


$\begin{array}{llll}\text { (28) } & \text { suffix } & \text { example } & \\ (28 \mathrm{a}) & \text {-te } & \text { filmte } & \text { 'film (pret.)' } \\ & \text {-chen } & \text { Häuschen } & \text { 'house (dim.)' } \\ & \text {-sel } & \text { Überbleibsel } & \text { 'remnant' } \\ (28 b) & \text {-ment } & \text { statement } & \\ & \text {-ness } & \text { lateness } & \\ & \text {-ful } & \text { faithful } & \end{array}$

Four possible representations for the words in (28) have been presented in (29), in which filmte is taken to be a representative example. Since the suffixes in (28) contain schwa they are clearly not dominated by their own feet or pwords (see Hall 1999b, Raffelsiefen 2000 for German and Raffelsiefen 1999b for English, who arrive at the same conclusion); hence, representation (29a) cannot be correct. (29b) is not the right representation because the final syllable of the stem violates the TMR by not being situated at the right edge of a pword. The two remaining possibilities are the recursive structure in $(29 \mathrm{c})$ or the one in $(29 \mathrm{~d})$ in which the suffix is situated outside of the pword of the stem and is linked to a higher contstituent in the prosodic hierarchy that is distinct from the pword. ${ }^{18}$
(29a) (film) $)_{\omega}(\text { te })_{\omega}$
(29b) (filmte) $)_{\omega}$
(29c) $\left((\text { film })_{\omega} \text { te }\right)_{\omega}$
(29d) (film) $)_{\omega}$ te

Since no compelling arguments come to mind in favor of $(29 \mathrm{c})$ over $(29 \mathrm{~cd})$ or vice versa, I leave this question open for further study.

My conclusion concerning the pword structure of examples like the ones in (28) has consequences for previous proposals made in the literature on German concerning strings composed of stem + chen. I conclude this section by examining the alternatives proposed in the literature and by demonstrating that (29d) (or, alternatively (29c)) is the correct one.

A number of linguists have argued that stem + chen has the prosodic structure (29a) (see Noske 1990, Yu 1992a, Wiese 1996, Noske 1997). The argument these linguists give for this representation is that the rule of Dorsal Fricative Assimilation - the process whereby /ç/ assimilates in backness to a preceding central or back vowel - is restricted to applying only when the trigger and target are situated within the same pword, e.g. (tauch-en) $)_{\omega} /$ tau-çən/ [tauxən] 'dive'. Since no assimilation occurs in words like Tau-chen 'rope (dim.)' [tauçən], *[tauxən], the phonologists cited above draw the conclusion that stem + chen must have

\footnotetext{
${ }^{18}$ For studies in which recursive pwords have been proposed see Zec \& Inkelas (1991) for Serbo-Croatian, Peperkamp (1997) for the Neapolitan dialect of Italian and Wiese (1996) for German compound words.
} 
representation (29a). As I noted above, the structure in (29a) cannot be correct because the second pword contains schwa as the nuclear element. The generalization concerning the domain of Dorsal Fricative Assimilation can still be maintained given the correct structure in (29d). Here the /ç/ does not become [x] because this segment does not belong to the same pword of the stem. ${ }^{19}$

Iverson \& Salmons (1992) argue that German has two -chen suffixes, the first of which is cohering $(=(29 b))$, and the second of which is noncohering, which the authors interpret to mean (29a). The first structure is argued to be correct for words like the ones in (30a) and the second for $(30 \mathrm{~b})$ :

\begin{tabular}{|c|c|}
\hline (30a) Häus-chen & 'house (dim.)' \\
\hline Bäum-chen & 'tree (dim.)' \\
\hline (30b) Tau-chen & 'rope (dim.)' \\
\hline Pfau-chen & 'peacock (dim.)' \\
\hline Tant-chen & 'aunt (dim.)' \\
\hline
\end{tabular}

The dichotomy between cohering and noncohering -chen is said to be supported by the fact that (i) /ç/ in -chen does not assimilate to $[\mathrm{x}]$ in the noncohering representation in (30b) and (ii) only the stems with cohering -chen undergo Umlaut, whereas the latter do not. Hence, Iverson \& Salmons (1992) assume that Umlaut, like Dorsal Fricative Assimilation, only operates when the suffix and the stem belong to the same pword. ${ }^{20}$

Significantly, the vast majority of German words containing -chen belong to the cohering group in (30a); hence, a consequence of Iverson \& Salmons' (1992) treatment is either that the pword is not the correct domain of the TMR, or the examples in (30a) constitute idiosyncratic exceptions to it. In my treatment the correct representation for - chen in both (30a) and (30b) is $(29 \mathrm{~d})$ (or $(29 \mathrm{c})$ ), since both -chen's can attach to trimoraic stems. With respect to the domain of German Umlaut it is noteworthy that Umlaut alternations occur regardless of whether or not a suffix is cohering or noncohering, e.g. Haus vs. Häus-er 'houses', häus-lich 'domestic'. These examples are important because they tell us that Umlaut cannot be analyzed as a rule that only applies when the trigger and target belong to the same pword.

\footnotetext{
${ }^{19}$ Wiese (1996: 69-72) presents a second argument for treating-chen as a separate pword. In particular, he argues that the element that deletes in coordinate structures is a pword; since-chen deletes (e.g. Brüder-und Schwesterchen 'brother (dim.) and sister (dim.)' from Brüderchen und Schwesterchen), he concludes that it is also a pword. As pointed out by Hall (1999b) and Smith (2000) the coordinate structure deletion data do not involve the deletion of a pword. Instead, the remnant, i.e. that portion of the complex word left over after deletion, is a pword.

${ }^{20}$ Sce also Féry (1995: 207\%), who argues that productive Umlaul, as in the examples in (30a), requires a syllabic trochee consisting of the last syllable of the stem and the suffix-chen.
} 


\subsection{Prefixed words}

The generalizations pertaining to the prosodic structure of stem + suffix sequences above also hold for strings consisting of prefix + stem. The words in the second column of (31) contain trimoraic stems that attach to the trimoraic prefixes in the first column.

$\begin{array}{llll}\text { (31) } & \text { prefix } & \text { example } & \\ \text { (31a) } & \text { aus- } & \text { Ausfahrt } & \text { 'driveway' } \\ & \text { auf- } & \text { Aufstieg } & \text { 'ascent' } \\ & \text { vor- } & \text { Vorstoß } & \text { 'dash' } \\ & \text { durch- } & \text { Durchzug } & \text { 'passage (through)' } \\ \text { (31b) fore- } & \text { forewarn } & \\ \text { post- } & \text { post-date } & \\ \text { trans- } & \text { trans-act } & \\ \text { out- } & \text { out-stare } & \end{array}$

The correct prosodic structures for these words have been illustrated in (32a) for the German word Aufstieg and (32b) for the English word forewarn respectively (see Raffelsiefen 2000: 50ff.):

(32a) auf ftik

(32b) fo:I wa.m

Note that German and English differ crucially with respect to relative prominence, as indicated with the subscripts ' $s$ ' and ' $w$ ' in the structures in (32). The reason the subscripts are appended to the pword and not to the foot is that the respective stems can consist of more than one foot, e.g. German unspektakulär 'unspectacular' (prosodically (un) ( (spektakulär) ${ }_{\omega}$, where the underlined vowels bear some stress and are hence the heads of feet. The stress pattern in (32a) and (32b) also holds for prefix + stem, where the prefix (or stem) is bimoraic. For example, German prefixes like $a n$ - and $u n$-, which are bimoraic, have the same stress pattern as the trimoraic ones in (31a), i.e. the prefix bears primary stress. The same generalization is true for English prefixes, e.g. in-, un-, which are stressed like the trimoraic ones in (31b).

The prosodic structures in (32) — in particular the adjacent pwords - derive support from two independent sources. First, these structures are in line with the TMR, since the trimoraic syllables are final in the resepctive pwords. And second, the rules predicting the stress patterns in (32a) and (32b), refer crucially to pwords and not so some other constituent (Raffelsiefen 
2000). In particular, for German a prefix that is a pword is metrically more prominent than the stem to which it attaches, but for English the reverse relation holds.

The following examples consist of unstressed German prefixes followed by trimoraic stems:

\begin{tabular}{|c|c|c|}
\hline prefix & example & \\
\hline ge- & gelernt & 'learned (part.)' \\
\hline be- & bewölkt & 'cloudy' \\
\hline ver- & Verrat & 'treason' \\
\hline zer- & zerfurcht & 'furrowed' \\
\hline er- & Erfolg & 'success' \\
\hline ent- & entfernt & 'distant' \\
\hline
\end{tabular}

Consider first $b e$ - and $g e$-. That these two prefixes cannot be independent pwords (or feet) is attested by the fact that the vowel is schwa. Hall (1999b) and Raffelsiefen (2000) argue independently that ge-and $b e$-cannot belong to the pword of the stem and conclude that the correct prosodic structure for words with these prefixes is the one in (34a).

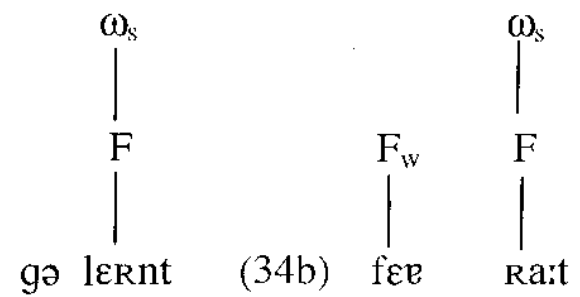

Consider now ver-, zer- and er-. The pronunciation dictionaries do not agree on whether or not these syllables constitute reduced forms (i.e. Krech et al. 1982 transcribe the nuclear portion of these three prefixes as [e] and Drosdowski et al. 1995 as [عe]). I assume that the prosodic structure varies, depending on the pronunciation: when they surface with the reduced vowel [e], I assume the structure in (34a) is the correct one and when the three prefixes ver-, $z e r-$, er- are realized as [ce], then they are dominated by a (weak) foot (see also Wiese 1996: 94ff.). Since the TMR does not require ver-, zer- and er- to be separate pwords, and since no positive evidence to my knowledge suggests this structure, I assume that representation (34b) is correct.

(34b) is also the correct structure for ent- (see also Wiese 1996: $94 \mathrm{ff}$. and Raffelsiefen 2000: 46-47). The reason ent- cannot be dominated by ist own pword is that this structure would not be in line with the rule discussed after (32) above, which says that a prefix that is a pword is metrically more prominent than the stem to which it attaches. I account for the fact that the prefix ent-is not in line with the TMR by analyzing this morpheme as exceptionally 
bimoraic as opposed to trimoraic (see note 6 and $\$ 6.3$ below for an analysis of exceptional moraic structure for English words).

\section{Systematic and idiosyncratic exceptions to the TMR}

As noted above in $\$ 4$, in both German and English the TMR has a number of systematic exceptions, i.e. words containing trimoraic syllables that occur within and not at the end of a pword. Both languages also have a small number of idiosyncratic exceptions. The former are discussed in $\$ 6.1-\$ 6.5$ and the latter in $\$ 6.6$.

The systematic exceptions to the TMR are significant for two reasons. First, they can be shown to follow from an OT-based model by ranking a small number of universal markedness constraints referring to syllable structure among themselves, or by ranking various markedness constraints ahead of the TMR. Second, the constraints posited below function as parameters that differentiate German and English.

\subsection{Syllabification of $\mathrm{V}: \mathrm{CCV}$}

Many German and English words contain a bimoraic string (= long vowel, diphthong or short vowel+consonant) followed by $\mathrm{CCV}$ within a pword. I abbreviate such bimoraic sequences henceforth as V:. Were the first of the two adjacent C's in such strings to be syllabified in syllable-final as opposed to syllable-initial position, i.e. V:C.CV, then such words would constitute violations to the TMR. Since many German and English words are of the form V:CCV we are therefore dealing with a large class of potential counterexamples to the TMR. In this section I argue that words containing V:CCV typically do not violate the TMR since they are syllabified V:.CCV for independent reasons. Under certain circumstances to be made explicit below, V:CCV is parsed V:C.CV. I account for such TMR violations by ranking constraints in an OT-based approach. ${ }^{21}$

\subsubsection{German}

Consider first how German words of the form VCCV are parsed in which the first $\mathrm{C}$ is more sonorous than the second, e.g. Tante 'aunt' [tantə]. There is unanimous agreement in the literature on German phonology that such words are parsed VC.CV, e.g. [tan.tə] - a syllabification that is motivated by various language internal arguments (see the discussion after (23)). The three markedness constraints in (35a), all familiar from the pre- and post-OT literature, when ranked as in (35c), predict the correct syllabification, as shown in the tableau in $(35 \mathrm{~d})$. In $(35 \mathrm{a})$ and below SSG $=$ SONORITY SEQUENCING GENERALIZATION (see, for example, Selkirk 1984, Clements 1990 and references cited therein). For purposes of this

\footnotetext{
${ }^{21}$ In this article I only discuss the parsing of $\mathrm{V}(\mathrm{s}) \mathrm{CCV}$ when $\mathrm{CC}$ represents an obstruent and a sonorant in either order. Both German and English have many words of the form V:CCV, where $\mathrm{CC}=$ two obstruents, e.g. English Easter, German Kloster [klo:ste] 'monastery'. As I pointed out in note 10, I assume that the parsing V:.sCV is correct because the $\mathrm{C}$ in both English and German is unaspirated in this environment.
} 
article I am assuming the sonority hierarchy in (35b) (see Clements 1990 for a similar hierarchy and Hall 1992 and Wiese 1996 for similar proposals for German).

(35a) (i) SSG: The syllable peak is preceded and/or followed by a sequence of segments with progressively decreasing sonority values.

(ii) ONSET: Syllables are consonant-initial

(iii) NoCODA: Syllables are open

(35b) Sonority Hierarchy: vowels $>$ glides $>r>$ l $>$ nasals $>$ obstruents

(35c) SSG, ONSET » NOCODA

(35d)

\begin{tabular}{|c|c|c|c|}
\hline & SSG & ONSET & NoCODA \\
\hline$\rightarrow[\tan . t \ominus]$ & & & * \\
\hline [ta.nto] & $* !$ & & \\
\hline$[\operatorname{tant} . \vartheta]$ & & $* !$ & * \\
\hline
\end{tabular}

Clearly German ranks faithfulness constraints that prevent the insertion of vowels and the deletion of consonants (i.e. DEP-V and MAX-C respectively) higher than NoCODA; this is necessary to account for the fact that a surface form like [tan.tə] is better than [ta.nV.tə] or [ta.to]. ${ }^{22} 23$

Note that the first vowel in the example Tante is short. Were a long vowel to occur before $\mathrm{CCV}$ then the constraint ranking in $(35 \mathrm{c})$ would predict a syllabification that would lead to a TMR violation, namely V:C.CV. Barring the systematic exceptions to be discussed in $\$ 6.2$ and $\$ 6.4$ such examples do not exist, i.e. hypothetical words like [tain.tə] are nonoccurring. That this is a true systematic gap can be gleaned from the nativized pronunciation of loan words containing VNOV or VLOV, in which the first vowel is stressed and tense, e.g. Spanish J[u]nta > German J[U]nta, Polish/Czech P[o]lka > German P[o]lka. In German stressed tense vowels are always long; that the stressed vowels in such examples are realized as lax and short rather than tense and long attests to the importance of the TMR.

Consider now German examples which contain V:CCV in which $\mathrm{CC}$ exhibits a sonority rise. The words in (36) have been divided into three groups based on the nature of the adjacent

\footnotetext{
${ }^{22}$ Note that the ranking ONSET » NOCODA in $(35 \mathrm{c})$ also correctly predicts that $\mathrm{V}(:) \mathrm{CV}$ is parsed $\mathrm{V}(\mathrm{:}) \mathrm{CV}$. As I noted in (23) above, this parsing (as opposed to $\mathrm{V}(\mathrm{)}) \mathrm{C} . \mathrm{V}$ ) is correct because the $\mathrm{C}$ never undergoes processes that hold in coda position, e.g. Final Devoicing and $r$-Vocalization. Many German words are of the form VCV, in which the $\mathrm{C}$ is preceded by a short vowel, e.g. Bitte [bita] 'request', Roggen [Rogan] 'rye'. Most investigators have argued that the $\mathrm{C}$ in such examples is not in absolute syllable-initial position, but instead that it is ambisyllabic (see Ramers 1992, Wiese 1996 and references citcd therein). If such parsings are correct then the present analysis requires an additional constraint that predicts that the optimal syllabification for a word like Bitte is [bita] (with an ambisyllabic [t]) as opposed to [bI.tə]. The nature of this constraint is not important for purposes of this articlc.

${ }^{23}$ Recall from (6) that I analyze final coronal obstruents not as stray, as in (10b), but instead as moraic, as in (10a). Since obstruents occupy a single position in the sonority hicrarchy in (35b) the analysis presented up to this point incorrectly predicts that the [t] in a word like Markt cannot be parsed. This point is discussed in detail in Hall (2000).
} 
C's. In (36a) the two C's can also occur word-initially, e.g. [gn bl dR] in Gnade 'mercy', Blitz 'lightning', drei 'three'. By contrast, in (36b) and (36c) the two C's cannot occur wordinitially, i.e. no German word begins with [dl $\mathrm{dn}$ çn çm]. The difference between (36b) and (36c) is that in the former words the first $\mathrm{C}$ in $\mathrm{V}: \mathrm{CCV}$ is a voiced obstruent and in the latter words it is voiceless. In (36b) and (36c) I only give five examples of CC sequences that occur word-medially but not word-initially; however, additional examples for both groups can be found in the literature (e.g. Hall 1992, Giegerich 1992a, Yu 1992b).

\begin{tabular}{|c|c|c|c|}
\hline (36a) & regn-en & [Re:gnən] & 'rain (verb)' \\
\hline & nebl-ig & [ne:bliç] & 'foggy' \\
\hline & zylindr-isch & [tsylindRif] & 'cylindrical' \\
\hline 6b) & Adler & [a:dle] & 'eagle' \\
\hline & Handl-ung & [handlun] & 'plot (noun)' \\
\hline & ordn-en & [ordnun] & 'order (verb) \\
\hline $6 \mathrm{c})$ & zeichn-en & [tsaiçnən] & 'draw' \\
\hline & Atm-ung & [a:tmun] & 'breath' \\
\hline
\end{tabular}

I hold that all of the words in (36) are parsed V:.CCV. This syllabification is uncontroversial in the examples in (36a), since these onsets occur in word-initial position; what is more, this parsing derives support from the fact that voiced obstruents do not undergo Final Devoicing. The same reasoning implies that the syllabification V:.CCV is also correct for the examples in (36b) (see Hall 1992, Giegerich 1992b, Yu 1992b), since the post-V: obstruent does not undergo Final Devoicing. ${ }^{24}$ More controversial is the parsing V:.CCV in the words in (36c), e.g. [tsar.çnən] for zeichnen. Since these onsets are nonoccurring word-initially, one might be tempted to assume that these words are parsed V:C.CV, e.g. [tsarç.nən], but we already know on the basis of words like the ones in (36b) that the LOI (recall (3iii)) is not exceptionless in German. In contrast to the examples in (36a) and (36b) no language internal argument exists supporting either the parsing [tsarç.nən] or [tsar.çnən]. Note, however, that the adjacent C's in (36c), like those in (36a) and (36b), constitute a sonority rise when syllable-initial (recall the sonority hierarchy in (35b)). Hence, syllabifications like [tsai.çnən] not only enable us to

\footnotetext{
${ }^{24}$ See, however, Rubach (1992), who argues for the parsing V:C.CV in words like Handlung. Problematic for Rubach's approach are monomorphemic words like Adler.

Two examples of words like the ones in (36b) in which the parsing VC.CV appears to be correct are Widmung [vitmun] 'dedication' and Kadmium [katmium] 'cadmium'. That the $/ \mathrm{t}$ in these words was historically a /d/ suggests that this segment was (at that point in time) syllable-final and not syllable-initial. The reason these are only apparent examples for the parsing VC.CV in Modern Standard German is that the vowcl preceding the $/ \mathrm{t} /$ is short and not long. As I mentioned in note 22 most researchers agree that the $\mathrm{C}$ in VCV is ambisyllabic if the first $\mathrm{V}$ is short. If this generalization is correct for the obstruent in VONV as well, then the /t/ in words like Widmung and Kadmium is ambisyllabic in Modern Standard German. That the historical /d/ in these examples was devoiced suggests that at one point in time this segment was in absolute syllable-final position. It is beyond the scope of the present study to determine under which conditions obstruents in VONV were syllabified into absolute syllable-final position and then later reanalyzed as ambisyllabic.
} 
eliminate a large number of potential counterexamples to the TMR, they also make sense from the point of view of universal preference laws, i.e. they display a sonority rise consisting of an obstruent and a sonorant consonant in syllable-initial position.

I argue that the syllabification of the words in (36) falls out in an OT-based approach from the two constraints in (37a), the constraints SSG and NoCODA from (35ai) and (35aiii) respectively, and the language-specific ranking for German in (37b). The LOI in (37aii) has been repeated from (3iii).

(37a) (i) *COMPLEX: Onsets consisting of more than one member are illicit

(ii) LOI: In (VC.CV) $)_{\theta}$, CC does not occur word-initially.

(37b) SSG » NOCODA », LOI, *COMPLEX

Given the ranking for German in (37b), $\mathrm{V}: \mathrm{CCV}$ is consistently parsed V:.CCV, when the second $\mathrm{C}$ is more sonorous than the first. This point is made clear in the following two tableaus. In (38a) we see three candidates for the word regnen [Re:.gnən] 'rain (verb)', which is representative of the words in (36a). The second candidate loses out to the first because it violates the higher ranked NoCODA twice; by contrast, the winner violates the same constraint only once. In (38b) two candidates are evaluated for the German word Adler, which is representative of (36b) and (36c). The LOI is not crucial in the evaluation of such words. By contrast, this constraint plays an important role in English (see \$6.1.2).

\begin{tabular}{r||c|c|c} 
& SSG & NoCODA & $*$ COMPLEX \\
\hline \hline$\rightarrow$ [Re:.gnən] & & $*$ & $*$ \\
\hline [Re:g.nən] & & $* ! *$ & \\
\hline [Re:gn.ən] & $* !$ & $* *$ & \\
\hline
\end{tabular}

(38b)

\begin{tabular}{r||c|c|c|c} 
& SSG & NoCODA & LOI & $*$ COMPLEX \\
\hline \hline$\rightarrow$ aa.dle] & & & $*$ & \\
\hline$[$ a:d.le] & & $* !$ & & \\
\hline
\end{tabular}

Several linguists have noted that the voiced obstruents in examples like the ones in (36a) and (36b) can undergo Final Devoicing (see Vennemann 1972, Wiese 1988, Hall 1992, Giegerich 1992a). This pronunciation is usually described as being typical for a different dialect than Standard German, or a different speech register, i.e. fast/casual speech. Four representative examples have been presented in (39): 
(39)

$\begin{array}{lll}\begin{array}{l}\text { regn-en } \\ \text { nebl-ig }\end{array} & \text { [Re:knən] } & \text { 'rain (verb)' } \\ \text { Handl-ung } & \text { [hantlon] } & \text { 'foggy' } \\ \text { ordn-en } & \text { [oxtnən] } & \text { 'plot (noun)' } \\ \end{array}$

If, as the linguists listed above assume, the application of Final Devoicing is indicative of the parsing V:C.CV, then examples like the ones in (39) violate the TMR. From a formal point of view, I account for these TMR violations by positing that for this variety of German ${ }^{*}$ COMPLEX is ranked ahead of TMR. What is more, NoCODA cannot be ranked ahead of *COMPLEX, as in (38), but instead the reverse holds: *COMPLEX » NoCODA. These rankings are summarized in (40a) and illustrated with two candidates for the word regnen in the tableau in (40b). In this tableau I do not consider the constraints necessary to predict that $/ \mathrm{g} / \mathrm{is}$ devoiced (=Final Devoicing).

$$
\text { * COMPLEX » NOCODA, TMR }
$$

\begin{tabular}{r||c|c|c} 
& $*$ COMPLEX & NoCODA & TMR \\
\hline \hline [Re:g.nən] & & \multirow{2}{*}{$*$} \\
\hline [Re:.gnon] & $* !$ & & $*$ \\
\hline
\end{tabular}

\subsubsection{English}

Consider now the following English words, all of which contain VCCV or V:CCV. As in the German examples in (36), the CC sequence in (41) exhibits a sonority rise.

\begin{tabular}{|c|c|c|}
\hline \multirow[t]{3}{*}{ (4la) } & caprice & {$\left[\mathrm{k}^{\mathrm{h}} \partial \mathrm{p}^{\mathrm{h}} \mathrm{xi} \mathrm{s}\right]$} \\
\hline & attract & 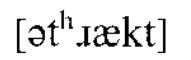 \\
\hline & acrue & {$\left[\partial \mathrm{k}^{\mathrm{h}} \mathrm{xu} \mathrm{i}\right]$} \\
\hline \multirow[t]{3}{*}{$(41 b)$} & atlas & {$\left[æ t^{2}\right.$ ləs] } \\
\hline & catkin & {$\left[\mathrm{k}^{\mathrm{h}} æ \mathrm{t}^{\mathrm{l}} \mathrm{km}\right]$} \\
\hline & acne & {$\left[\mathfrak{k k}^{?} \mathrm{ni}\right]$} \\
\hline
\end{tabular}

The words in (41) have been placed into two separate groups. In (41a) the adjacent C's, i.e. /pI $\mathrm{t} \mathrm{s} \mathrm{k} /$, occur word-initially (e.g. price, trade, cry) and in (41b) they do not, i.e. $/ \mathrm{tl} \mathrm{tl} \mathrm{kn} /$.

The allophones of $/ \mathrm{p} \mathrm{t} \mathrm{k} /$ provide evidence that the word-medial CC clusters in (41a) are syllable-initial (i.e. V.CCV) and the ones in (4lb) are heterosyllabic (i.e. VC.CV or V:C.CV). Since $/ \mathrm{p} \mathrm{t} \mathrm{k/} \mathrm{are} \mathrm{aspirated} \mathrm{in} \mathrm{(41a),} \mathrm{they} \mathrm{are} \mathrm{syllable-} \mathrm{(and} \mathrm{foot-)} \mathrm{initial.} \mathrm{By} \mathrm{contrast,} \mathrm{/p} \mathrm{t} \mathrm{k/} \mathrm{are}$ glottalized in (41b), indicating that they are syllable-final. Recall from $\$ 3.2$ that Glottalization is uncontroversially considered to apply in coda position. The data in (41b) are significant 
because they differ from the corresponding German examples in (36b), in which phonological evidence (i.e. the nonapplication of Final Devoicing) suggests the parsing V:.CCV.

English words like the ones in (41a) are correctly parsed as V.CCV with the ranking SSG » NOCODA »*COMPLEX that was established in (38a) for German. This is illustrated in tableau (42a), in which three candidates for the word acrue are evaluated. English words like the ones in (4lb) are parsed as VC.CV or V:C.CV with the language-specific ranking SSG, LOI » NoCODA "*COMPLEX. This is shown in the tableau in (42b), in which two candidates for the word atlas are evaluated. In both tableaus I ignore the surface allophones of voiceless stops.

\begin{tabular}{r||c|c|c} 
& SSG & NoCODA & $*$ COMPLEX \\
\hline \hline [ə.k..ui] $]$ & & & $*$ \\
\hline [ək.ru:] & & $* !$ & \\
\hline [ək.t.u:] & $* !$ & $* !$ & \\
\hline
\end{tabular}

(42b)

\begin{tabular}{r||c|c|c|c} 
& SSG & LOI & NOCODA & $*$ COMPLEX \\
\hline \hline [æt.ləs] & & & $* *$ & \\
\hline$[æ . t l ə s]$ & & $* !$ & $*$ & $*$ \\
\hline
\end{tabular}

A number of linguists (see below) have noted that in English syllabification is crucially dependent on whether or not the vowel before one or more C's is stressed or unstressed. In words like the ones in (4la) the syllable preceding the two C's is unstressed, in which case most researchers agree that the two C's are situated in the following onset, i.e. V..CCV. By contrast, when the first vowel is stressed, as in (43), phonologists either assume that the first C is ambisyllabic (see Kahn 1976, Gussenhoven 1986), or that it is in absolute syllable-final position (see Selkirk 1982, Hammond 1999):

$\begin{array}{ll}\text { apron } & \text { [erpıən }] \\ \text { patron } & {\left[\mathrm{p}^{\mathrm{h}} \text { eItıən }\right]} \\ \text { cobra } & {\left[\mathrm{k}^{\mathrm{h}} \text { oub.əə }\right]}\end{array}$

I reject the proposed syllabification $\mathrm{V}: \mathrm{C} . \mathrm{CV}$ in such words because a phonological argument from English suggests that the first $\mathrm{C}$ not be syllable-final: Evidence against the parsing V:C.CV is that the first $\mathrm{C}$ is not glottalized, i.e. ${ }^{*}\left[\mathrm{p}^{\mathrm{h}} \mathrm{ert}^{\text {? }} . \mathrm{I}\right.$.ən]. Instead, I follow Kahn (1976) and Gussenhoven (1986) in analyzing the first of the two adjacent C's in words like the ones in (43) as ambisyllabic. The ambisyllabic representation for the words in (43) does not violate the TMR because the ambisyllabic $\mathrm{C}$ is not dominated by its own mora. For example, the [p] in apron is linked to the second of the two moras that dominate the long vowel and not to a third mora. 
Accounting for the syllabification of the English data in (41) in an OT-based approach is a relatively simple matter, as shown in the rankings and tableaux in (42) above. By contrast, it remains to be shown how ambisyllabic consonants in examples like the ones in (43) can be predicted to occur given surface constraints. I leave open the question of how such constraints should be stated formally.

\subsection{Syllabification of $\mathrm{V}: \mathrm{CjV}$}

The German words in (44) contain a sequence of $\mathrm{V}: \mathrm{CjV}$. In (44a) the $\mathrm{C}$ in this string is an obstruent and in (44b) it is $/ \mathrm{R} /$, which undergoes $\mathrm{r}$-Vocalization to [ $\mathrm{e}$ ]. The transcriptions in (44) are based on Duden (Drosdowski et al. 1990): ${ }^{25}$

$\begin{array}{llll}\text { (44a) } & \begin{array}{l}\text { Studium } \\ \text { Radio }\end{array} & \text { [ftu:.djum] } & \text { 'studies' } \\ \text { [Ra:.djo] } & \text { 'radio' } \\ \text { (44b) } & \text { Orient } & \text { [o:e.jent] } & \text { 'orient' } \\ & \text { Ferien } & \text { [fe:e.jen] } & \text { 'vacation' } \\ \text { Karies } & \text { [ka:e.jəs] } & \text { 'cavity' } \\ & \text { Bakterie } & \text { [bak.te:e.jə] } & \text { 'bakteria' }\end{array}$

Vater (1992) notes that even the pronounciation dictionaries cannot agree on whether or not the $i$ in words like the ones in (44b) is to be pronounced as a glide (transcribed here as [i]) or a vowel (=[i]). According to Drosdowski et al. (1990) the $i$ in (44b) (and (44a)) is a glide and not a vowel. By contrast, Krech et al. (1982) transcribe the $i$ in the words in (44a) as a glide and the ones in (44b) as [i] and write explicitly that $i$ in the latter words is pronounced as a vowel (p. 32). In the first part of this section I account for the data in (44) and in the second part I analyze the data in Krech et al. (1982).

Consider first the examples in (44a). In all of these words the pre-[j] consonant is a voiced. Since this sound does not undergo Final Devoicing we can safely conclude that it is situated in the onset. Hence, a word like Studium is syllabified [ftui.djum] and not [ftu:d.jum], and since the first syllable is open, this parsing does not violate the TMR. The parsing V:CjV falls out from the ranking SSG » NOCODA » *COMPLEX, which was established on the basis of the data in (36) and illustrated in the tableau in (38a). ${ }^{26}$

\footnotetext{
${ }^{25}$ Some of the studies devoted to the distribution of German glides include Moulton (1962), Klocke (1982), Vater (1992), Hall (1992) and Wiese (1996). None of these linguists propose an analysis for German glides that is akin to the one presented in this section.

${ }^{26}$ Recall from (39) that certain varietics of German have the option of syllabifying the first of two adjacent Cs in $\mathrm{V}(:) \mathrm{CCV}$ in the coda of the first syllable. By contrast, this parsing is not possible for the examples in (44a), i.e. the pronunciation [ftu:tjum] is incorrect. I assume that forms such as [ftut.jum] are ruled out by virtue of the fact that they pose worse violations to the SYLLABLE CONTACT LAW (see Murray \& Vennemann 1983 and Vennemann 1988) than forms like [Re:k.nən] (for regnen). I do not pursue this possibility here and simply leave it open for further study.
} 
An examination of the phonetic form of the examples in (44b) reveals that $/ R /$ is vocalized. Since $r$-vocalization uncontroversially takes place in coda position (see the discussion after (23)) the implication is that these words are parsed /VR.jV/, e.g. /ka:R.jəs/ (=[kare.jəs]) and not /kai.Rjos/. Since the vocalized-R is preceded by a long vowel, the examples in (44b) are significant because they all violate the TMR.

The words in (44b) do not conform to the TMR because the latter constraint is outranked by a higher one barring syllable-initial [Rj]. Assuming the sonority hierarchy in (35b), [Rj] cannot occur in syllable-initial position because the two segments are too close together on this scale (see Vennemann 1988: 44 for discussion on the avoidance of syllable-initial [r]+glide in Germanic); hence, the constraint barring syllable-initial [Rj] can be thought of as being a consequence of the constraint in (45a), which I call MINIMAL SONORITY DISTANCE (MSD) (see Selkirk 1984 for a pre-OT treatments of minimal sonority distance requirements in English). For purposes of this article I assume that the MSD refers specifically to [Rj]:

(45a) MSD: $[\mathrm{Rj}]$ is a nonoccurring onset

(45b) MSD » TMR

Given the language-specific ranking for German in (45b) the correct output forms in (44b) can be obtained. This is illustrated in the following tableau for Karies:

\begin{tabular}{|c|c|c|}
\hline & MSD & TMR \\
\hline$\rightarrow$ [kair.jəs] & & $*$ \\
\hline [ka:.rjəs] & $* !$ & \\
\hline
\end{tabular}

That ' $R$ ' in the winning candidate in (46) is phonetically [e] is accomplished with additional constraints that do not concern us here. ${ }^{27} 28$

According to Krech et al. (1982: 32) the $i$ after $/ \mathrm{R} /$ is predictably [i] or [i], depending on the location of word stress. When the syllable before $/ \mathrm{R} /$ is stressed, then [i] surfaces, as in (47a) below. By contrast, when the vowel following $i$ is stressed, $i$ surfaces as [j], as in $(47 \mathrm{~b}):^{29}$

\footnotetext{
${ }^{27}$ German also has words containing V:CjV where the $\mathrm{C}$ is a lateral or a nasal, e.g. Familie [lami:ljə] 'family', Linie [linjol 'line'. It is unclear whether or not $[\mathrm{l}]$ and $[\mathrm{n}]$ in these and similar words are syllable-initial or syllable-final. If the latter parsing is correct then this would suggest that the MSD be reformalized as a constraint barring onsets consisting of a sonorant consonant followed by [j]. If $[1]$ and $[\mathrm{n} \mid$ are syllable-initial then the MSD in (45a) is correct and the parsing $\mathrm{V}: \mathrm{Cj \textrm {V }}$, where $\mathrm{C}$ is a liquid or nasal, is a consequence of the ranking in (38a).

${ }^{28}$ One cannot predict that [ka:R.jas] is better than [ka:.Rjas]] with the ranking *COMPLEX » NoCoDA because German requires the opposite ranking of these two constraints (sec (37b) and (38a)).

29) See also Drosdowski et al (1990: 35): „Vor unbetontem Vokal wird [i] nach [r] nicht so leicht unsilbisch wie vor betontem Vokal....".
} 


\begin{tabular}{|c|c|c|c|}
\hline \multirow[t]{4}{*}{$(47 a)$} & Orient & ['O:RiEnt] & 'orient' \\
\hline & Ferien & ['fe:Ricn] & 'vacation' \\
\hline & Karies & ['ka:Rios] & 'cavity' \\
\hline & Bakterie & [bak'te:Ri.ə] & 'bakteria' \\
\hline \multirow[t]{3}{*}{$(47 b)$} & äquatorial & [ekvatov'ja:l] & 'equatorial' \\
\hline & bakteriell & [baktev'jel] & 'bakterial' \\
\hline & kurios & [kue'jo:s] & 'curious' \\
\hline
\end{tabular}

The curious stress condition only makes sense when one considers the length of the vowel preceding /R/. A number of writers have observed that German has long tense vowels like [i: u: e:] as well as short tense vowels like [i u e] which are in complementary distribution: The long vowels surface when stressed and the short ones when unstressed (see Reis 1974, Ramers 1988, Wiese 1988, Hall 1992, Wiese 1996). Examples can be gleaned from the words in (47). In (47a) the stressed vowels are all long and tense and in (47b) the unstressed vowels preceding $/ \mathrm{R} /$ are short. If 'short' and 'long' translate into single and bimoraic structures respectively, we see that the reason $/ \mathrm{R} /$ can be syllabified into the coda in (47b) (and subsequently undergo $r$-Vocalization) is that this segment is preceded by a monomoraic syllable. By contrast, $/ R /$ in (47a) cannot be syllabified into the coda because this segment is preceded by a bimoraic syllable. Put differently, the data in (47) show that for Krech et al. (1982) the TMR and the MSD are equally ranked. ${ }^{30}$

\subsection{Exceptional moraic structure}

As pointed out by Borowsky (1986, 1989), syllable-final sequences in English like VCC and $\mathrm{V}: \mathrm{C}$ can violate her equivalent of the TMR when the final $\mathrm{C}$ or $\mathrm{CC}$ satisfy certain requirements (made specific below) concerning the place of articulation. In the following paragraphs I present an alternative account of such morpheme-internal sequences as being exceptionally bimoraic.

The underlined strings in the English words in (48) all appear to violate the TMR, since they are all pword-internal. In all of these examples the underlined string consists of a short vowel + nasal + homorganic stop, which I abbreviate henceforth as VNS. These words consist of monomorphemic and polymorphemic words.

$\begin{array}{ll}\text { empty } & \text { extinction } \\ \text { pumpkin } & \text { instinctive } \\ \text { bumpkin } & \text { rambunctious } \\ \text { sphincter } & \text { bumptious }\end{array}$

\footnotetext{
${ }^{30}$ In V:CjV sequences in English, e.g. union, chameleon, the TMR would be violated given the parsing V:C.jV.I leave open how such words should be syllabified. Interestingly, there are no English words of the form V(:).j. $\mathrm{V}$.
} 


$\begin{array}{ll}\text { apopemptic } & \text { scrumptious } \\ \text { plankton } & \underline{\text { unctuous }} \\ \text { symptom } & \text { puncture } \\ \text { handsome } & \text { assumption }\end{array}$

Note that the segment following the VNS string in (48) is a stop or fricative. Although some English words contain a syllable-final VNS before a liquid or nasal, e.g. antler, ointment, I do not group together such examples with the ones in (48) for reasons to be made explicit below. Instead, I treat word with VNS followed by a sonorant as idiosyncratic exceptions to the TMR (see $\$ 6.6$ ).

Equivalent German examples containing a pword-internal VNS followed by an obstruent have been presented in (49). As in English the underlined strings in the German words occur in both monomorphemes and polymorphemic words. ${ }^{31}$

\begin{tabular}{|c|c|c|c|}
\hline Plankton & 'plankton' & Adjunkte & 'adjunkts' \\
\hline Symptom & 'symptom' & disjunktiv & 'disjunktive' \\
\hline Funktion & 'function' & Punkte & 'periods' \\
\hline Interpunktion & 'punctuation' & distinkte & 'distinct (nom. sg. fem.)' \\
\hline Disjunktion & 'disjunction' & Instinkte & 'instinkts' \\
\hline Sanktion & 'sanction' & prompte & 'prompt (nom. sg. fem.)' \\
\hline
\end{tabular}

Apparrently there are no German words like antler and ointment in which the segment following a syllable-final VNS is a nasal or a liquid.

I account for the data in (48) and (49) by analyzing the underlined strings as exceptionally bimoraic. This is accomplished with the constraint in $(50 \mathrm{a})$, which I call VNS.

(50a) VNS: A syllable-final VNS is parsed as bimoraic if an obstruent follows.

(50b) VNS $» 3-\mu$

The VNS is crucially ranked ahead of $3-\mu$ (recall ( 11 aii)), as shown in (50b) - a ranking that ensures that a syllable-final VNS sequence is parsed as bimoraic rather than trimoraic. ${ }^{32}$

\footnotetext{
${ }^{31}$ Note that the obstruent after VNS in the words in (49) is an anterior coronal, i.c. [t $\left.\overline{t s}\right]$. That labial, velar and postalveolar obstruents are nonoccurring in this context is a consequence of a general phonotactic constraint ensuring that the second of two adjacent (intervocalic) obstruents is an anterior coronal, i.e. sequences like $[\mathrm{VkpV}]$ and $[\mathrm{VpkV}]$ are nonoccurring. The same gencralization holds for English, although there are some exceptions, c.g. napkin.

${ }^{32}$ Recall from note 6 that I analyze English [0:I] as exceptionally bimoraic, since this sequence can be followed by noncoronal obstruents in word-final position, e.g. fork, absorb, born. Given this treatment it is not surprising that [o:I] can surface within a pword in apparent violation of the TMR, e.g. morning, orgy, Mormon.
} 
Interestingly, there is a strong tendency to delete the S in VNS precicely in the context in $(50 \mathrm{a})$, i.e. before an obstruent, when $S$ shares the same place features with a preceding nasal. For example, a word like empty can be pronounced [empti] or [Emti] (see Borowsky 1989: 161). Several authors have noted that the post-sonorant stop in German examples like the ones in (49) can optionally delete as well (see, for example, Hall 1992: 117-118). Indeed, the optional deletion of the $\mathrm{S}$ in VNS before an obstruent is the reason why $\mathrm{I}$ do not consider words like antler and ointment to belong in (48).

The underlined strings in English words like the ones in (51) also appear to violate the TMR (see Borowsky 1986, 1989 who makes this observation). Monomorphemes have been presented in (5la) and stem + vowel-initial suffixes in (5lb). The examples in (51) are all similar in the sense that the final consonant of the underlined strings shares the same place of articulation with the following consonant; thus, sequences like [e:m] and [e:n] are followed by [b] and [d] respectively. I refer to the underlined strings in (51) henceforth as V:N.

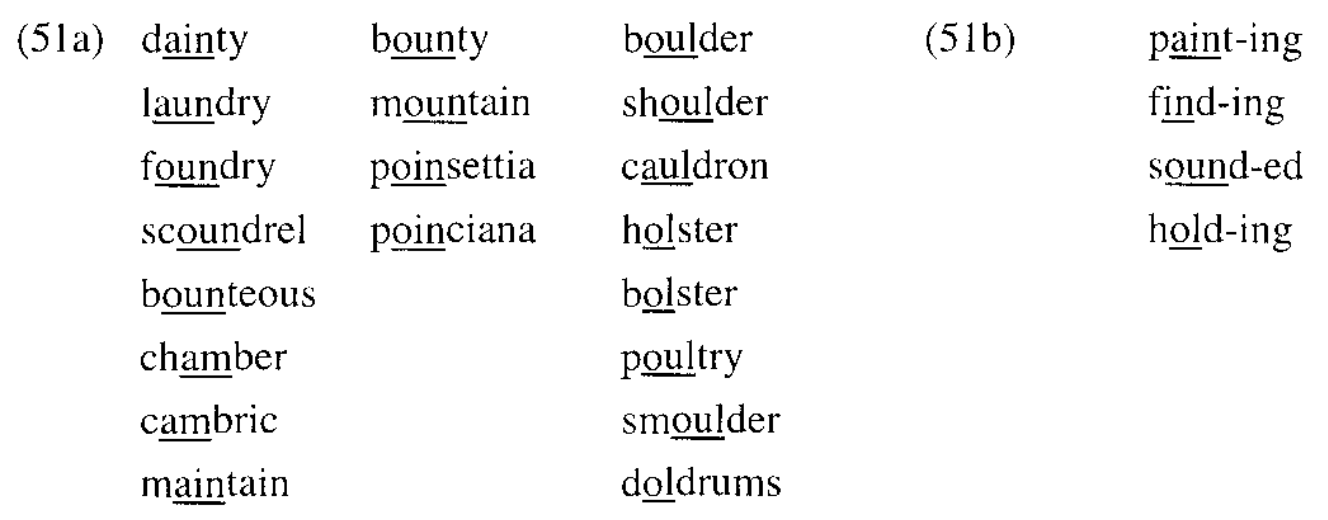

The data in (51) reveal that the consonant following $\mathrm{V}: \mathrm{N}$ is a homorganic obstruent. ${ }^{33}$

A comparison of the English examples in (51) with the German forms in (52) reveals a significant difference between the two languages. While there are many monomorphemic English words like the ones in (51a), corresponding German examples are nonoccurring. By contrast, German permits heteromorphemic words like the ones in (52), in which the final nasal in the underlined string is homorganic with the following stop:

$\begin{array}{ll}\text { Freund-e } & \text { 'friends' } \\ \text { Mond-e } & \text { 'moons' } \\ \text { Feind-e } & \text { 'enemies' } \\ \text { Fahnd-ung } & \text { 'search' }\end{array}$

\footnotetext{
${ }_{33}$ Borowsky (1989) considers words like ancient, danger and angel to belong to the examples in (51) as well. The status of the V:N strings in such words is not clear because the sound that follows [n] is postalveolar, i.e. [t] $\overline{\mathrm{d}}]$, and hence not homorganic with the preceding [n].
} 
In the remainder of this section I concentrate only on the English examples in (51) and return to the corresponding German words in (52) in the following section.

I propose the constraint in (53a), which ensures that V:N is parsed as bimoraic when the $\mathrm{N}$ shares the same place node as the following obstruent:

(53a) V:N: A syllable-final $\mathrm{V}: \mathrm{N}$ is parsed as bimoraic if an obstruent follows that is homorganic with $\mathrm{N}$.

(53b) $\quad \mathrm{V}: \mathrm{N} \gg 3-\mu$

The language-specific ranking in (53a) ensures that a string $\mathrm{V}: \mathrm{N}$ in words like chamber is parsed as bimoraic and not trimoraic.

Borowsky $(1986,1989)$ argues that the underlined strings in English words like chamber in (51a) (as well as (48)) can be explained by appealing to Hayes' (1986) Linking Constraint. Specifically, she argues that her equivalent of the TMR makes reference to a single line of association between the root node and the place node. Since the $\mathrm{N}$ and following $\mathrm{C}$ in (51) all share the place node, there exists a multiple link between two root nodes and a single place node and the Linking Constraint predicts that the relevant constraint should not hold. The upshot is that Borowsky's treatment allows morpheme-internal strings like $\mathrm{V}: \mathrm{N}$ in words like chamber since they do not violate her constraint.

The problem with Borowsky's solution is that she employs the Linking Constraint as a diacritic. As pointed out by Hayes (1986) the Linking Constraint can only be invoked to block a constraint (or rule) if there exists an independent reason for formalizing it with a single line of association between the relevant tiers. I reject Borowsky's analysis because there is no such independent motivation for requiring that the TMR (or Borowsky's equivalent thereof) refer to a line of association between the root and place nodes.

\subsection{Morphologically related words}

An additional set of systematic counterexamples to the TMR are the German words in the first column of (54) (see also (52)). Note that all of these German examples are heteromorphemic and that the underlined string occurs in the stem. In (54a) the final segment in the underlined trimoraic syllable is a nasal $(=[n])$ that is homorganic with the following stop or fricative. By contrast, in (54b) the final consonant of the underlined sequence is not homorganic with the following consonant. All of the stem + suffix sequences in (54) are parsed as single pwords by (2iii) because the suffix is vowel-initial. 


\begin{tabular}{|c|c|c|c|}
\hline \multirow[t]{14}{*}{$(54 a)$} & derived word & stem & \\
\hline & Mond-e & Mond & 'moons' \\
\hline & Freund-e & Freund & 'friends' \\
\hline & Freund-in & Freund & 'female friend' \\
\hline & sich an-freund-en & Freund & 'make friends' \\
\hline & Feind-e & Feind & 'enemies' \\
\hline & An-feind-ung & Feind & 'hostility' \\
\hline & sich ver-feind-en & Feind & 'become enemies' \\
\hline & Fahnd-ung & fahnd- & 'search (noun)' \\
\hline & fahnd-en & fahnd- & 'search (inf.)' \\
\hline & einst-ig & einst & 'once' \\
\hline & $\underline{\text { ernst-e }}$ & ernst & 'serious' \\
\hline & $\underline{\text { Ernte }}$ & ernt- & 'harvest \\
\hline & Dienst-es & Dienst & 'service' \\
\hline \multirow[t]{14}{*}{$(54 b)$} & $\underline{\text { Obst-es }}$ & Obst & 'fruit' \\
\hline & nächst-e & nächst & 'next' \\
\hline & Markt-es & Markt & 'market' \\
\hline & Häupt-e & Haupt & 'chief' \\
\hline & feucht-e & feucht & 'damp’ \\
\hline & leicht-e & leicht & 'light' \\
\hline & feilsch-en & feilsch- & 'bargain (verb)' \\
\hline & fürcht-en & Furcht & 'fear' \\
\hline & beicht-en & beicht- & 'confess' \\
\hline & leucht-en & leucht- & 'shine' \\
\hline & jauchz-en & jauchz- & 'shout for joy' \\
\hline & rülps-en & rülps- & ‘burp’ \\
\hline & seufz-en & seufz- & 'sigh' \\
\hline & verleumd-en & verleumd- & 'slander' \\
\hline
\end{tabular}

One cannot invoke the constraint V:N posited in (53a) to account for the German examples in (54a) for two reasons. First, this approach would not explain the absence of German monomorphemes like chamber, and second, it would fail to account for the existence of TMR violations in the underlined strings in $(54 \mathrm{~b})$.

The reason the underlined sequences in (54) are systematic counterexamples to the TMR is that they are all the derived forms of the corresponding stems. In all of the bare stems in (54) the identical segment structure is preserved in the derived forms; hence, the data in (54) 
illustrate 'paradigm uniformity'. ${ }^{34}$ Put differently, the reason the underlined strings in (54) violate the TMR is that there is pressure to avoid allomorphy by keeping the paradigms intact. ${ }^{35}$ Formally I adopt the constraint LeVEL in (55a) (from Raffelsiefen 1995: 28ff.). In contrast to pinut-output faithfulness consitraints, e.g. MAX-IO and DEP-IO, LEVEL compares the surface forms in a paradigm.

(55a) LEVEL: All members of a paradigm must have identical forms.

(55b) MAX- $\mu$ : No deletion of a mora.

(55c) MAX- $\mu \gg$ TMR, LEVEL

In addition to LEVEL my analysis requires the faithfulness constraint MAX- $\mu$ in (55b), which penalizes any output form in which an underlying mora has been deleted. Given the ranking for German in (55c) the violations to the TMR in (54) can all be accounted for, as I demonstrate below.

Let us consider the pair $\{$ Obst, Obstes $\}$ as a representative example of a 'paradigm' in (54). Four possible paradigms (or, 'candidate sets') are presented in (56), which differ in terms of the length of the initial vowel. In (56) and below the moraic structure is assumed to be a function of the corresponding segment structure; hence, the stem syllable in all eight phonetic forms are trimoraic. MAX- $\mu$ violations are determined by comparing the length of the vowel in both the nonderived form and the derived form with the (bimoraic) $/ o:$ in the underlying form /o:pst/.

\begin{tabular}{clll} 
A & \multicolumn{1}{c}{ B } & \multicolumn{1}{c}{ C } & D \\
$([\text {.o:pst. }])_{\omega}$ & $\left([\text {.o:pst.] })_{\omega}\right.$ & $(\text { [.opst.] })_{\omega}$ & $(\text { [.opst.] })_{\omega}$ \\
$\left([\text {.o:p.stəs.] })_{\omega}\right.$ & $(\text { [.op.stəs.] })_{\omega}$ & $(\text { [.o:p.stəs.] })_{\omega}$ & $(\text { [.op.stəs.] })_{\omega}$
\end{tabular}

Compare first the winner A with candidate sets B and C. While A violates the TMR once (in [.o:p.stəs.]), it is completely faithful to LEVEL and to MAX- $\mu$. By contrast, the candidate sets in $\mathrm{B}$ and $\mathrm{C}$ reveal that LEVEL and MAX- $\mu$ are violated once. Consider now the tableau in (57). The reason MAX- $\mu$ (and not LEVEL) is ranked crucially ahead of TMR can be deduced by examining candidate set D. Here LEVEL and TMR are satisfied, but MAX- $\mu$ is violated twice:

\footnotetext{
${ }^{34}$ By 'identical stem structure' I mean specifically vowel and consonant length. For example, a stem ending in $\mathrm{V}: \mathrm{CC}$ preserves $\mathrm{V}: \mathrm{CC}$ when a suffix is added.

${ }^{35}$ Some of the recent literature on the role of paradigm uniformity in phonology includes Raffelsiefen (1995), Kenstowicz (1996), Benua (1997), and Steriade (1999). See also Kager (1999: chapter 4) for a synthesis on the recent litcrature on this topic. Paradigm uniformity has enjoyed a long tradition in linguistics. For carlier studies see Kuryłowicz (1949) and Kiparsky (1982).
} 
(57)

\begin{tabular}{r||c|c|c} 
& MAX- $\mu$ & LEVEL & TMR \\
\hline \hline $\mathrm{A}$ & & & $*$ \\
$\mathrm{~B}$ & $* !$ & $*$ & $*$ \\
$\mathrm{C}$ & $* !$ & $*$ & $*$ \\
\hline $\mathrm{D}$ & $* ! *$ & $*$ \\
\hline
\end{tabular}

A final remark needs to be made concerning the words in (54). In some of these examples we see stem alternations, e.g. in the pair $\{$ Mond, Mondes $\}$ in (54a) the bare stem is pronounced [mo:nt] but as [mo:nd] with the suffix -es. In (54b) we see that in the paradigm \{Haupt, Häupt-e\} only the latter stem exhibits Umlaut of the stem vowel. What these examples tell us is that LEVEL is dominated by other constraints that allow for allomorphy. I do not present a formal analysis of these examples here, since it would detract from the main issues dealt with in the present paper. Let us simply posit that constraints necessary to account for Final Devoicing and other alternations must be higher ranked than TMR. ${ }^{36}$

\subsection{Prosodic compounds}

In this section I discuss German and English words in which a trimoraic syllable surfaces within a polysyllabic morpheme. I argue that such morphemes should be analyzed as prosodic compounds, i.e. they are identical to compound words in terms of prosodic but not morphological structure. In contrast to the examples discussed in $\$ 6.1-\$ 6.4$, the prosodic structures I posit below do not fall out from constraint rankings, but instead derive historical motivation.

The underlined sequences in the monomorphemic German words in the first column of (58) appear to violate the TMR. In (58) and below MHG = Middle High German.

$\begin{array}{lll}\text { Antwort } & \text { MHG antwürte } & \text { 'answer' } \\ \underline{\text { Antlitz }} & \text { MHG antlitze } & \text { 'face' } \\ \underline{\text { Urlaub }} & \text { MHG urloup } & \text { 'vacation' } \\ \underline{\text { Ursprung }} & \text { MHG ursprunc } & \text { 'cause' }\end{array}$

The existence of a trimoraic structure internal to a morpheme in the examples in (58) has the same explanation: These words are historically of the form prefix + stem, where the underlined portion subsumes the moraic structure of the prefix. Consider first Antwort and Antlitz. The Ant- in both of these forms is historically the (primarily stressed) prefix ant-, which, in the vast majority of other German words which contained it, reduced to ent-, c.f. entfernt 'distant' in (33), in which the stem and not the prefix is stressed. By contrast, the Ant- in the

\footnotetext{
${ }^{36}$ In German there is to my knowledge one example of a morpheme containing a long vowel in the underived form, namely Polen Ipo:.lon] 'Poland', which is shortened upon suffixation, cf. poln-isch [pol.nIf] 'Polish'. Since this is the only example of a morpheme violating LEVEL, I assume it is a lexically listed exception.
} 
first two words in (58) retained its stress and therefore did not reduce. In Modern Standard German the earlier morphological structure is completely opaque; hence the words Antwort and Antlitz are perceived as monomorphemic. The same generalization pertains to Urlaub and Ursprung, both of which contain the historical prefix $U r$-, but which are perceived as monomorphemes. ${ }^{37}$

I analyze the examples in (58) as prosodic compounds, i.e. as words that are analyzed as compound words from the point of view of prosodic structure and not morphological structure. ${ }^{38}$ Put differently, all of the words in (58) are monomorphemes from the point of view of morphology, but the prosodic structure is the same as in true prefix + stem forms in which the prefix is stressed (see (32a)). Thus, in the development from MHG to Modern Standard German the morphological structure changed but the prosodic structure remained intact.

Let us now consider the nature of the prosodic representations for the words in (58), in particular foot- and pword-structure. With respect to the former constituent, one could either say the examples in (58) are dominated by (i) a single trochaic foot, or (ii) two separate monosyllabic feet. I adopt (ii) and reject (i) because only the former but not the latter can account for the fact that the words in (58) are stressed like compounds (e.g. Bahnhof) and prefix + stem words where the prefix is stressed, e.g. Aufstieg. In other words, the second syllable in the Modern German words in (58) bears secondary stress. In order to capture the generalization that the first foot in words like Antwort is strong (=primary stress) and the second weak (=secondary stress) the first pword is labeled s (=strong) and the second one w (=weak) (recall prefixed words like Aufstieg in (32a)). Taking the pword into consideration, there are two possible representations, i.e. (59a) and (59b), for the examples in (58). I hold that (59a) is correct for the words in (58) but that other German (and English) words discussed below require the structure in $(59 \mathrm{~b})$.

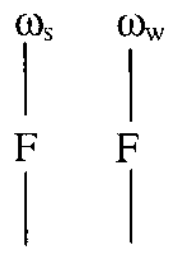

(59a) ant voet

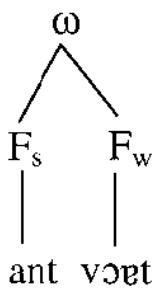

The analysis presented in the preceding sections provides two reasons for (59a) and against (59b). First, the first syllable in (59b) but not (59a) violates the TMR. Second, the rule

\footnotetext{
${ }^{37}$ Modern German still retains the productive prefix Ur-, e.g. Uroma 'great-grandma'.

${ }^{38}$ See also Becker (1996: 276-278), who considers German words like the ones in (58), as well as proper names to be Scheinkomposita, i.e. words that are prosodically but not morphologically compounds. However, Becker does not say explicitly how such examples should be represented prosodically in terms of feet and pwords. Raffelsiclen (2000: 45) argues similarly that certain words, c.g. Abenteuer 'adventure' that were etymologically never compounds are 'pseudo-compounds'; i. c. grammatical words composed of more than one pword.
} 
referred to in $\$ 5$ which predicts that the prefix in prefix + stem is primarily stressed is correctly satisfied only in (59a) but not in (59b) (recall that this constraint refers to two adjacent pwords). ${ }^{39}$

Note that the pwords in representation (59a) cannot be predicted based on the algorithm presented in (2). The reason ant-and $U r$ - as well as the elements to which they attach in (59) cannot be parsed as pwords is that these sequences of sounds are neither stems marked for a lexical category, nor (stressed) prefixes. That ant-and $U r$-are historical prefixes is not a part of the competence of native speakers, but the prefixal nature of ant-and $U r$-is captured in the prosodic structure alone. Since (2) cannot correctly parse ant-and $U r$ - as a pword, the pwords in representations like the one in (59a) are underlying.

Borowsky $(1986,1989)$ notes that her equivalent of the TMR does not govern proper nouns like the ones in (60). If these items are monomorphemic words (=single pwords), then they violate the TMR:

$\begin{array}{ll}\text { Elmhurst } & \text { Siegmund } \\ \text { Kingsley } & \text { Kleinhenz } \\ \text { Grimsby } & \text { Bernhard } \\ \text { Greenberg } & \text { S } \underline{\text { alzburg }}\end{array}$

I analyze names like the ones in (60) as prosodic compounds, i.e. (59a) is the correct representation. This structure is supported by the fact that the stress pattern of the names in (60) is identical to the stress pattern of compound words with primary stress on the first constituent, e.g. MSG Bahnhof 'train station' ['ban., ho:f]. In fact, some of the names in (60) are obviously compounds, e.g. Salzburg. It is also significant that names like the ones in (60) behave as two pwords in other respects. For example, one property shared by proper names and compounds in German is that they allow a sequence of [tk], e.g. Bratkartoffeln 'fried potatoes', Edgar, whereas this sequence is ruled out morpheme-internally. Examples of

\footnotetext{
${ }^{39}$ See also Booij (1999: 59-60), who argues that certain Dutch words have the representation (59a). Giegerich (1985: $77 \mathrm{ff}$.) analyzes words like the ones in (58) as morphological compounds in order to explain why the first syllable and not the final one is stressed. The present treatment captures the generalization that these words behave phonologically as two words but morphologically as one.

Additional examples of German and English words in which the TMR is violated in a bound stem include certain days of the week, as in (i) and (ii):
(i) Montag 'Monday'
Dienstag 'Tuesday'
Samstag 'Saturday'
(ii) Tucsday
Wednesday

That the second part of the examples in (i) and (ii) (i.e. -tag and-day) bears secondary stress implies that these words consist of two separate feet. I assume that the correct prosodic structure for these examples is (59a), in which case the underlined strings in (i) and (ii) do not violate the TMR. This analysis is supported by the clymology of the respective stems, which were all once free morphemes corresponding to the names of Germanic gods.
} 
phonological generalizations in English that do not hold for proper names are discussed in Raffelsiefen (1993: 90-92). ${ }^{40}$

Additional examples of words that appear to violate the TMR have been listed in (61):

\begin{tabular}{|c|c|c|c|}
\hline (61a) Kaninchen & 'rabbit' & $(61 b)$ & gratefu \\
\hline Mädchen & 'girl' & & ruthless \\
\hline Radieschen & 'raddish' & & $\underline{\text { armlet }}$ \\
\hline Kürschner & 'furrier' & & \\
\hline Hälfte & 'half' & & \\
\hline
\end{tabular}

The examples in (61) are similar in the sense that they contain a 'bound root' plus a 'suffix'. Two typical examples are the words Kaninchen and Mädchen in (61a). These items are synchronically monomorphemic but they were once heteromorphemic, i.e. MHG kaninchen meant 'rabbit (dim.)', which was formed productively from the noun kanin 'rabbit'. The latter word eventually dropped out of the language, at which point the meaning of Kaninchen became lexicalized. Mädchen similarly derives from Early New High German (ENHG) Mägdchen 'maiden (dim.)'on the basis of the stem Magd 'maiden'. If the TMR has been active since MHG then MHG Kaninchen and ENHG Mägdchen were clearly not exceptions to the TMR. The first part of the English words in (61b) was similarly at one point in the history of English an occurring free form (grate < Latin grātus 'agreeable'; ruth-< Middle English rewthe 'remorse').

Although the morphological boundaries in (61) were lost, the prosodic structure was retained. Thus, in Modern Standard German and Modern English the pword structure of the examples in (61) is as in (62). Note that these representations are identical to the ones posited earlier for true stem + suffix sequences in which the suffix contains a reduced vowel (see $(31 \mathrm{~d}))$.
(62a) (Kanin) $)_{\omega}$ chen
(62b) (grate) $)_{\omega 0}$ ful
(Mäd) $)_{\omega}$ chen
(ruth) $)_{\omega}$ less
(Radies) ${ }_{\omega}$ chen
$(\mathrm{arm})_{\omega} \mathrm{let}$
(Kürsch) $)_{\omega}$ ner
(Hälf) $)_{\omega}$ te

Since the 'bound roots' in (62) are not true morphological stems that are marked for lexical category membership, I assume that the pword structure in (62) is underlying.

\footnotetext{
${ }^{40}$ Other proper names cannot be represented prosodically as in $(59 a)$ because the second syllable contains a reduced vowcl, e.g. Ruhnke [Ru:n.kə], and Dresden [dRes.s.dən]. I assume that examples like these are represented as in (62) below.
} 
The words in (58) and (60) show that it is possible for the morphological sructure to become opaque historically but that the pword (and foot) structure remains intact. In contrast to the examples in (58) and (60), many words in German and English have undergone both a morphological and a prosodic restructuring. Examples of historical compound words that have restructured to single pwords are listed in (63) (from Raffelsiefen 1993, 1999a, Booij 1999):

$\begin{array}{ll}\text { business } & \text { postman } \\ \text { cupboard } & \text { shepherd } \\ \text { breakfast } & \end{array}$

A comparison of the phonetic representation of the words in (63) with the phonetic form of the words from which they derive indicates that the prosodic restructuring triggered various segmental processes, e.g. the deletion of [i] in business, the reduction of [pb] to [b] in cupboard, the reduction of unstressed vowels to schwa in breakfast, postman and shepherd.

The German examples in (64) underwent a restructuring or pwords as in the English examples in (63):

$\begin{array}{lll}\text { Himbeere } & \text { MHG hintber } & \text { 'rasberry' } \\ \text { Brombeere } & \text { MHG brāmber } & \text { 'blackberry' }\end{array}$

These words are etymologically compounds; in contrast to MSG, the first part of hintber and brāmber were attested in MHG as free morphemes, i.e. MHG hinde, MSG 'Hirschkuh', MHG bräme MSG 'Dornstrauch'. If, as suggested above, the TMR were active in MHG, then these original compounds had the pword structure in the first column of (65). I assume that the loss of hinde and brāme as free morphemes meant that the first part of the original compounds could not be parsed as a pword, since hinde and brame had lost their status as stems marked for a lexical category. Since the trimoraic syllables violated the TMR they were subsequently shortened. $^{41}$

$$
\begin{array}{lll}
\text { (hint })_{\omega}(\text { ber })_{\omega} & (\text { Himbeere })_{\omega} & \text { 'rasberry' } \\
(\text { bräm })_{\omega}(\text { ber })_{\omega} & (\text { Brombeere })_{\omega} & \text { 'blackberry' }
\end{array}
$$

There is, however, an important difference between the prosodic restructuring that occurred in the English examples in (64) and in the Modern German ones in (65): The former words are composed of a single pword and a single (trochaic) foot, whereas the Modern German

\footnotetext{
${ }^{41}$ Clearly, one needs to account for why the prosodic restructuring as in (65) occurred in these examples but not in others. For example, the prosodic structure of the days of the week (see note 39) were not restructured into single pwords. In this particular case I assume that the prosodic structure in the days of the week was retained because these are highly frequent words.
} 
examples in (65) consist of a single pword and two feet. Thus, the representation in (59b) above is the correct one for MSG words like Himbeere and Brombeere.

\subsection{Idiosyncratic exceptions}

The following is a list of German and English words in which the underlined sequences violate the TMR. Since none of these words can be grouped together with any of the systematic counterexamples discussed in $\$ 6.1-\$ 6.4$, I refer henceforth to these words as idiosyncratic exceptions to the TMR. The English examples are all of the ones presented in Borowsky $(1986,1989)$ that I cannot otherwise explain, as well as some examples of my own. I make no claims concerning the completeness of the list in (66).

\begin{tabular}{|c|c|c|c|}
\hline Partner & 'partner' & partner & polka \\
\hline Skulptur & 'sculpture' & sculpture & harpsichord \\
\hline arktisch & 'arctic' & $\underline{\operatorname{arctic}}$ & infarction \\
\hline Erde & 'earth' & seismic & beatnik \\
\hline Halfter & 'holster' & deictic & antler \\
\hline Auktion & 'auction' & auction & ointment \\
\hline Börse & 'stock exange' & apartment & \\
\hline Leutnant & 'lieutenant' & compartment & \\
\hline Müsli & 'Müsli' & department & \\
\hline
\end{tabular}

In light of the hundreds of thousands of trimoraic syllables in German and English that occur uncontroversially at the end of a pword, it is certainly noteworthy that the number of idiosyncratic exceptions in both languages is remarkably small. This point aside, there are three additional reasons why the words in (66) are interesting.

First, at least one of the trimoraic sequences in (66) is otherwise nonoccurring in the language as a whole, namely the German word Skulptur, which is apparently the only example of a word containing a syllable ending in [ulp]. Second, three of the trimoraic syllables in (66) are unstable and therefore tend to shorten, namely arctic and polka, and Börse. Borowsky (1986, 1989) notes that the [k] in the English word arctic tends to be elided in everyday speech; the same can be said for the [1] in polka. Both Krech et al. (1982) and Drosdowski et al. (1995) note that the long vowel [ø:] in Börse can optionally be pronounced as [œ]. Third, some of the underlined strings in (66) might not be trimoraic syllables to begin with if the final consonant were syllabified into the following onset, as opposed to the coda, which I assumed in (66), i.e. Modern German Müsli, Leutnant, Partner might be syllabified Mü.sli, Leu.tnant and Par.tner respectively. Interestingly, the analysis of German syllabification in $\$ 6.1$ predicts the latter syllabification. 


\section{Conclusion}

The cental thesis put forth in the present article is that in both German and English there is a constraint I call TMR that limits trimoraic rhymes to the final position in a pword. A second claim is that the TMR is violated in both languages in certain (predictable) cases and that these facts can be explained by ranking various markedness constraints ahead of the TMR in an OT framework. 


\section{References}

Aronoff, M. \& S. N. Sridhar 1983. "Morphological Levels in English and Kannada; or, Atarizing Reagan". Papers from the Paresession on Phonology, Morphology, and Syntax. Chicago 22.-23. April 1983. ed. by J. F. Richardson, M. Marks \& A. Chukerman, 3-16.

Becker, T. 1996. "Die Aufhebung des Vokallängengegensatzes in unbetonten Silben der deutschen Standardsprache". Deutsche Sprache ??: 268-282.

Benua, L. 1997. Transderivational Identity: Phonological Relations Between Words. Ph.D. dissertation. University of Massachusetts at Amherst.

Booij, G. 1983. "Principles and Parameters in Prosodic Phonology". Linguistics 21.249-280.

Booij, G. 1985. "Coordination Reduction in Complex Words: A Case for Prosodic Phonology". Advances in Nonlinear Phonology. ed. by H. van der Hulst \& N. Smith, 143-160. Dordrecht: Foris.

Booij, G. 1999. "The Role of the Prosodic Word in Phonotactic Generalizations". In: T. A. Hall \& U. Kleinhenz (eds). Studies on the Phonological Word. 47-72. Amsterdam: John Benjamins.

Booij, G. \& J. Rubach 1984. "Morphological and Prosodic Domains in Lexical Phonology". Phonology Yearbook 1: 1-27.

Booij, G. \& J. Rubach 1987. "Postcyclic versus Postlexical Rules in Lexical Phonology". Linguistic Inquiry 18: 1-44.

Borowsky, T. 1986. Topics in the Lexical Phonology of English. Ph.D. dissertation. University of Massachusetts at Amherst [Published 1990: New York: Garland].

Borowsky, T. 1989. "Structure Preservation and the Syllable Coda in English". Natural Language and Linguistic Theory 7: 145-166.

Brockhaus, W. 1995. Final Devoicing in the Phonology of German. Tübingen: Niemeyer.

Clements, G. N. 1990. "The Role of the Sonority Cycle in Core Syllabification". In: J. Kingston \& M. E. Beckman (eds.) Papers in Laboratory Phonology I: Between the Grammar and Physics of Speech. 283-333. Cambridge: Cambridge University Press.

Clements, G. N. \& S. S. J. Keyser 1983. CV-Phonology: A Generative Theory of the Syllable. Cambridge, Mass.: MIT Press.

Cohn, A. C. 1989. "Stress in Indonesian and Bracketing Paradoxes". Natural Language and Linguistic Theory 7. 167-216.

Dixon, R. M. W. 1977a. A Grammar of Yidin. Cambridge: Cambridge University Press.

Dixon, R. M. W. 1977b. "Some Phonological Rules of Yidin"., Linguistic Inquiry 8.1-34.

Drosdowski, G. et al., Hrsg. 1990. Duden Aussprachewörterbuch. Wörterbuch der deutschen Standardaussprache. Band 4. Mannheim: Bibliographisches Institut.

Drosdowski, G. et al., Hrsg. 1995. Duden Grammatik. Band 6. Mannheim: Bibliographisches Institut.

Eisenberg, P. 1991. "Syllabische Struktur und Wortakzent. Prinzipien der Prosodik deutscher Wörter". Zeitschrift für Sprachwissenschaft 10: 37-64. 
Féry, C. 1995. Alignment, Syllable and Metrical Structure in German. Habilitationsschrift. University of Tübingen.

Féry, C. 1997. "The Mora as a Measure of Weight and Syllable Constituent". In: P. M. Bertinetto et al. (eds), Certamen Phonologicum III. Papers from the Third Cortona Phonology Meeting, April 1996. Torino, Rosenberg \& Sellier.

Féry, C. 1998. "German Word Stress in Optimality Theory". Journal of Comparative Germanic Linguistics 2: 101-142.

Fudge, E. 1969. "Syllables". Journal of Linguistics 5: 253-286.

Giegerich, H. 1985. Metrical Phonology and Phonological Structure. German and English. Cambridge: Cambridge University Press.

Giegerich, H. 1989. "Syllable Structure and Lexical Derivation in German". Bloomington: Indiana University Linguistics Club Publication.

Giegerich, H. 1992a. "Onset Maximization in German: The Case Against Resyllabification". In: P. Eisenberg, K. H. Ramers \& H. Vater (eds.) Silbenphonologie des Deutschen. 134-171. Tübingen: Narr.

Giegerich, H. 1992b. English Phonology. An Introduction. Cambridge: Cambridge University Press.

Green, A. D. 2000. "Extrasyllabic Consonants and Onset Well-Formedness". To appear in: C. Féry \& R. van de Vijver (eds.) The Syllable in Optimality Theory. Cambridge: Cambridge University Press.

Grijzenhout, J. 1998. "The Role of Coronal Specification in German and Dutch Phonology and Morphology". In: R. Wiese \& W. Kehrein (eds.) Phonology and Morphology of the Germanic Languages. 29-50. Tübingen: Niemeyer.

Gussenhoven, C. 1986. "English Plosive Allophones and Ambisyllabicity". Gramma 10: 119-141.

Hall, T. A. 1992. Syllable Structure and Syllable Related Processes in German. Tübingen: Niemeyer.

Hall, T. A. 1993. "The Phonology of German /R"'. Phonology 10: 83-105.

Hall, T. A. 1998. "A Note on Secondary Stress in German Prosodic Morphology". Linguistische Berichte 175: 414-424.

Hall, T. A. 1999a. "The Phonological Word: A Review”. In: T. A. Hall \& U. Kleinhenz (eds). Studies on the Phonological Word. 1-22. Amsterdam: John Benjamins.

Hall, T. A. 1999b. "Phonotactics and the Prosodic Structure of German Function Words". In: T. A. Hall \& U. Kleinhenz (eds). Studies on the Phonological Word. 99-131 Amsterdam: John Benjamins.

Hall, T. A. 2000. "The Status of Extrasyllabic Consonants in German and English". Ms.

Hammond, M. 1999. The Phonology of English. A Prosodic Optimality-Theoretic Approach. Oxford: Oxford University Press.

Hannahs, S. J. 1995a. Prosodic Structure and French Morphophonology. Tübingen: Niemeyer.

Hannahs, S. J. 1995b. "The Phonological Word in French". Linguistics 33. 1125-1144.

Hayes, B. 1986. "Inalterability in CV Phonology". Language 62: 321-351. 
Hayes, B. 1989. "Compensatory Lengthening in Moraic Phonology". Linguistic Inquiry 20: 253-306.

Hock, H. H. 1986. "Compensatory Lengthening: In defense of the concept 'mora"'. Folia Linguistica 20: $431-460$.

Hooper, J. 1976. An Introduction to Natural Generative Phonology. New York: Academic.

Hulst, H. van der 1984. Syllable Structure and Stress in Dutch. Dordrecht: Foris.

Hyman, L. 1985. A Theory of Phonological Weight. Dordrecht: Foris.

Inkelas, S. 1993. "Deriving Cyclicity". Studies in Lexical Phonology, ed. by S. Hargus \& E. Kaisse, 75-110. San Diego: Academic Press.

Iverson, G. \& J. Salmons 1992. "The Place of Structure Preservation in German Diminutive Formation". Phonology 9: 137-143.

Kager, R. 1989. A Metrical Theory of Stress and Destressing in English and Dutch. Dordrecht: Foris.

Kager, R. 1999. Optimality Theory. Cambridge: Cambridge University Press.

Kager, R. \& W. Zonneveld 1986. "Schwa, Syllables and Extrametricality". The Linguistic Review 5: 197-222.

Kahn, D. 1976. Syllable-Based Generalizations in English Phonology. Ph.D. Dissertation. MIT.

Kang, O. 1991. Korean Prosodic Phonology. Ph.D. Dissertation. University of Washington.

Kenstowicz, M. 1994. Phonology in Generative Grammar. Cambridge: Blackwell.

Kenstowicz, M. 1996. "Base Identity and Uniform Exponence: Alternatives to Cyclicity". In: J. Durand \& B. Laks (eds.) Current Trends in Phonology: Models and Methods. 363-393. Paris: CNRS.

Kenyon, J. S. \& T. A. Knot 1953. A Pronouncing Dictionary of American English. Springfield, Mass.: G. \& C. Meriam.

Kiparsky, P. 1966. "Über den deutschen Akzent”. Studia Grammatica VII: 69-98.

Kiparsky, P. 1981. "Remarks on the Metrical Structure of the Syllable". In: W. U. Dressler, O. E. Pfeiffer \& J. R. Rennison (eds.) Phonologica 1980. Akten der Vierten Internationalen PhonologieTagung, Wien, 29. Juni-2. Juli 1980. 245-256.

Kiparsky, P. 1982. Explanation in Phonology. Dordrecht: Foris.

Kloeke, W. U. S. van Lessen 1982. Deutsche Phonologie und Morphologie. Merkmale und Markiertheit. Tübingen: Niemeyer.

Krech, E.-M. et al. 1982. Großes Wörterbuch der deutschen Aussprache. Leipzig: VEB Bibliographisches Institut.

Kuryłowicz, J. 1949. "La nature des procès dits analogiques". Acta Linguistica 5: 15-37.

McCarthy, J. 1993. "A Case of Surface Constraint Violation". Canadian Journal of Linguistics 16: 169-195.

McCarthy, J. 2000. "The Prosody of Phase in Rotuman". Natural Language and Linguistic Theory 18: 147-197.

McCarthy, J. \& A. Prince 1986. "Prosodic Morphology". Unpublished Ms. 
Moulton, W. G. 1956. "Syllabic Nucleii and Final Consonant Clusters in German". In: M. Halle, H. G. Lunt \& H. McLean (eds.) For Roman Jakobson. 372-381. The Hague: Mouton.

Moulton, W. G. 1962. The Sounds of English and German. Chicago: University of Chicago Press.

Murray, R. W. \& T. Vennemann 1983. "Sound Change and Syllable Structure in Germanic Phonology." Language 59: 514-528.

Nespor, M. \& I. Vogel 1986. Prosodic Phonology. Dordrecht: Foris.

Noske, M. 1990. "Harmonic Phonology and the Distribution of Northern German [ç] and [x]". CLS 26: 333-348.

Noske, M. 1997. "Feature Spreading as Dealignment: The Distribution of [ç] and $[x]$ in German" Phonology 14: 221-234.

Peperkamp, S. 1997. Prosodic Words. The Hague: Holland Academic Press.

Prince, A. \& P. Smolensky 1993. "Optimality Theory". Ms.

Raffelsiefen, R. 1993: "Relating Words: A Model of Base Recognition. Part I". Linguistic Analysis 23: 3-159.

Raffelsiefen, R. 1995. "Conditions for Stability: The Case of Schwa in German". Theorie des Lexikons. Arbeiten des Sonderforschungsbereichs 282. Nr. 69. Düsseldorf.

Raffelsiefen, R. 1999a. "Diagnostics for Prosodic Words Revisited: The Case of Historically Prefixed Words in English". In: T. A. Hall \& U. Kleinhenz (eds). Studies on the Phonological Word. 133201. Amsterdam: John Benjamins.

Raffelsiefen, R. 1999b. "Phonological Constraints on English Word Formation". In: G. Booij \& J. van Marle (eds.) Yearbook of Morphology 1998. 225-287. Kluwer.

Raffelsiefen, R. 2000. "Evidence for Word-Internal Phonological Words in German". In: R. Thieroff, M. Tamrat, N. Fuhrhop \& O. Teuber (eds.) Deutsche Grammatik in Theorie und Praxis. 43-56. Tübingen: Niemeyer.

Ramers, K.-H. 1988. Vokalquantität und-qualität im Deutschen. Tübingen: Neimeyer.

Ramers, K.-H. 1992. "Ambisilbische Konsonanten im Deutschen." P. Eisenberg, K. H. Ramers \& H. Vater (eds.) Silbenphonologie des Deutschen. 246-283. Tübingen: Narr.

Reis, M. 1974. Lauttheorie und Lautgeschichte: Untersuchungen am Beispiel der Dehnungs- und Kürzungsvorgänge im Deutschen. München: Fink.

Roca, I. \& W. Johnson 1998. A Course in Phonology. Oxford. Blackwell.

Rochoń, M. 2000. Optimality in Complexity: The Case of Polish Consonant Clusters. Berlin: Akademie Verlag.

Rubach, J. 1992. "Final Devoicing and Cyclic Syllabification in German". Linguistic Inquiry 21: 7994.

Rubach, J. 1997. "Extrasyllabic Consonants in Polish: Derivational Optimality Theory". In: I. Roca (ed.) Derivations and Constraints in Phonology. 551-581. Oxford: Clarendon Press. 
Selkirk, E. O. 1978. "On Prosodic Structure and its Relation to Syntactic Structure". Nordic Prosody II. ed. by Thorstein Fretheim. Trondheim: TAPIR.

Selkirk, E. O. 1982. "The Syllable". In: H. van der Hulst \& N. Smith (eds.) The Structure of Phonological Representations. Part 1. 337-382. Dordrecht: Foris.

Sekirk, E. O. 1984. "On the Major Class Features and Syllable Theory". In: M. Aronoff \& R. Oehrle (eds.) Language Sound Structure. 107-137. Cambridge, Mass.: MIT Press.

Selkirk, E. 1995. "The Prosodic Structure of Function Words". Papers in Optimality Theory. ed. by J. N. Beckman et al., 439-469. Amherst.

Smith, G. 2000. "Word Remnants and Coordination". In: R. Thieroff, M. Tamrat, N. Fuhrhop \& O. Teuber (eds.) Deutsche Grammatik in Theorie und Praxis. 57-68. Tübingen: Niemeyer.

Spencer, A. 1996. Phonology. Oxford: Blackwell.

Stampe, D. 1973. A Dissertation on Natural Phonology. New York: Garland.

Steriade, D. 1999. "Paradigm Uniformity and the Phonetics-Phonology Boundary". In: M. Broe \& J. Pierrehumbert (eds.) Papers in Laboratory Phonology 5. 313-334. Cambridge: Cambridge University Press.

Vater, H. 1992. "Zum Silben-Nukleus im Deutschen”. In: P. Eisenberg, K. H. Ramers \& H. Vater (eds.) Silbenphonologie des Deutschen. 100-133. Tübingen: Narr.

Vennemann, T. 1972. "On the Theory of Syllabic Phonology", Linguistische Berichte 18: 1-18.

Vennemann, T 1982. "Zur Silbenstruktur der deutschen Standardsprache". In: Theo Vennemann (ed.) Silben, Segmente, Akzente. 261-305. Tübingen: Niemeyer.

Vennemann, T. 1988. Preference Laws for Syllable Structure and the Explanation of Sound Change. Berlin: Mouton.

Wennerstrom, A. 1993. "Focus on the Prefix: Evidence for Word-internal Prosodic Words". Phonology 10: 309-324.

Wiese, R. 1988. Silbische und lexikalische Phonologie. Studien zum Chinesischen und Deutschen. Tübingen: Niemeyer.

Wiese, R. 1991. "Was ist extrasilbisch im Deutschen und warum?". Zeitschrift für Sprachwissenschaft 10: 112-133.

Wiese, R. 1996. The Phonology of German. Oxford: Clarendon Press.

Withgott, M. M. 1982. Segmental Evidence for Phonological Constrituents. Ph.D. Dissertation: University of Rexas at Austin.

Wurzel, W. U. 1980. "Phonologie. Segmentale Struktur". In: K.-E. Heidolph et al. (eds.) Deutsche Grundzüge einer deutschen Grammatik. 898-990. Berlin: Akademie Verlag.

Yu, S.-T. 1992a. Unterspezifikation in der Phonologie des Deutschen. Tübingen: Niemeyer.

Yu, S.-T. 1992b. "Silbeninitiale Cluster und Silbifizierung im Deutschen". In: P. Eisenberg, K. H. Ramers \& H. Vater (eds.) Silbenphonologie des Deutschen. 172-207. Tübingen: Narr.

Zec, D. 1995. "Sonority Constraints on Syllable Structure?". Phonology 12: 85-129. 


\section{T. A. Hall}

Zec, D. \& S. Inkelas 1991. "The Place of Clitics in the Prosodic Hierarchy". Proceedings of WCCFL 10, ed. by D. Bates, 505-519. 